\title{
Kingdom of the Netherlands_-Aruba: Selected Issues and Statistical Appendix
}

This Selected Issues paper and Statistical Appendix for the Kingdom of the Netherlands-Aruba was prepared by a staff team of the International Monetary Fund as background documentation for the periodic consultation with the member country. It is based on the information available at the time it was completed on April 8, 2005. The views expressed in this document are those of the staff team and do not necessarily reflect the views of the government of the Kingdom of the Netherlands-Aruba or the Executive Board of the IMF.

The policy of publication of staff reports and other documents by the IMF allows for the deletion of market-sensitive information.

To assist the IMF in evaluating the publication policy, reader comments are invited and may be sent by e-mail to publicationpolicy@imf.org.

Copies of this report are available to the public from

International Monetary Fund $\bullet$ Publication Services

700 19th Street, N.W. • Washington, D.C. 20431

Telephone: (202) 6237430 • Telefax: (202) 6237201

E-mail: publications@imf.org • Internet: http://www.imf.org

Price: $\$ 15.00$ a copy

\section{International Monetary Fund Washington, D.C.}




\section{INTERNATIONAL MONETARY FUND \\ KINGDOM OF THE NETHERLANDS_ARUBA \\ Selected Issues and Statistical Appendix \\ Prepared by a staff team consisting of István P. Székely, \\ Céline Allard, and Evridiki Tsounta \\ Approved by the European Department}

April 8, 2005

Contents

Page

I. Long-run Growth and Fiscal Sustainability in Aruba...................................................

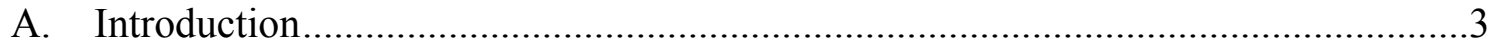

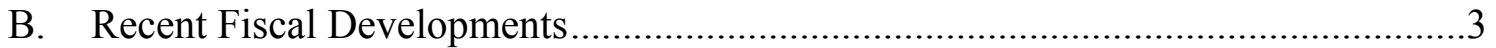

C. Medium-Term Fiscal Trends ............................................................................6

D. Long-term Fiscal Trends and the Impact of Aging ...........................................8

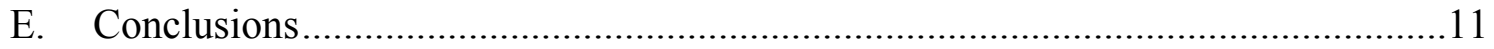

Figures

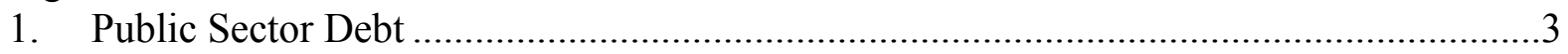

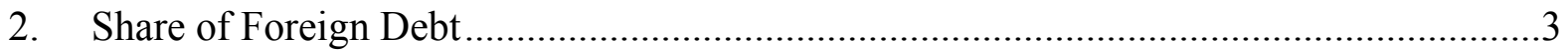

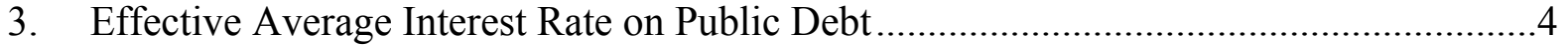

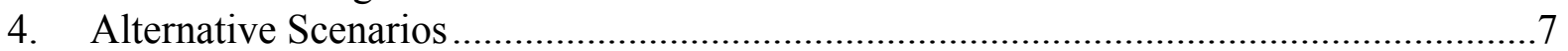

5. Old-Age-Related Balance ............................................................................... 9

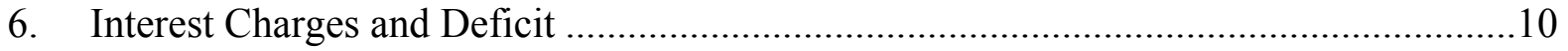

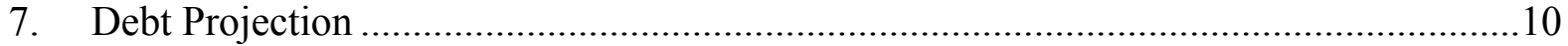

8. Debt Projection Under Alternative Scenarios.........................................................11

Tables

1. Comparison of Interest Payments with Other BBB-Rated Countries, 2003_..................5

2. GDP Growth Rate and Public Deficit for Aruba and the Euro Area ................................5

3. Medium-Term Fiscal Framework Under Unchanged Policies ......................................6

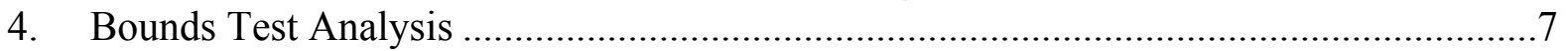

5. Population Projections to 2030 Under the No-Immigration Assumption.........................8

6. Long-Term Public Debt Sustainability Exercise, 2004-30 ......................................10 
Statistical Appendix Tables

A1. Indicators of Tourism Activity, 1995-2003 ………............................................12

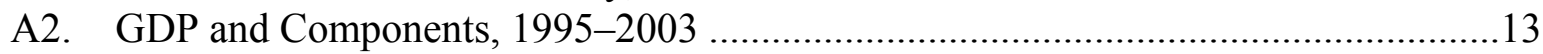

A3. Components in Percent of GDP, 1995-2003 …….................................................

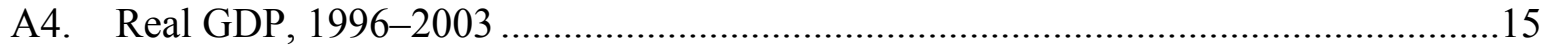

A5. Contributions to Real GDP Growth, 1996-2003 …………...................................16

A6. Changes in Consumer Price Index, 1996-2003 ……............................................17

A7. Legal Minimum Wages, 1995-2004 …………....................................................17

A8. Summary of Trends in Public Finance, 1995-2003 ………………………..............18

A9. Summary of Trends in Public Finance, 1995-2003 (In Percent of GDP) ..................19

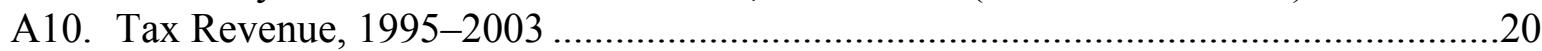

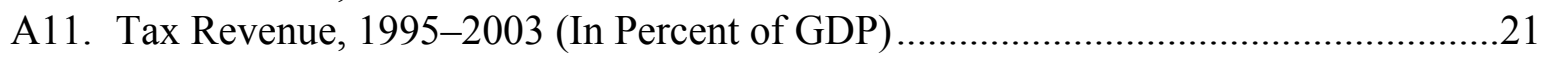

A12. Operational Budget of the Social Insurance Bank (SVB), 1996-2003 …..................22

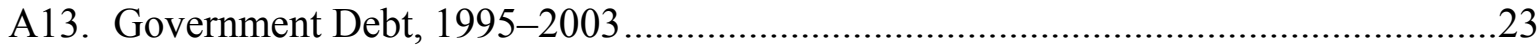

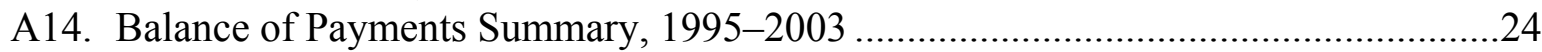

A15. Balance of Payments Summary, 1995-2003 ………...............................................

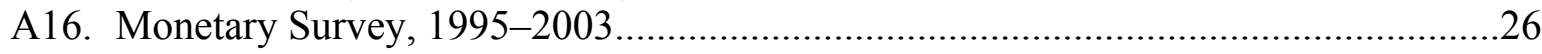

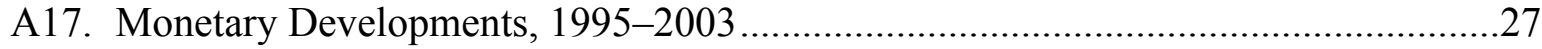

A18. Changes in Sources of Broad Money, 1995-2003 …………………………….......28 


\section{LONG-RUn Growth AND Fiscal SUSTAINABILITY IN ARUba ${ }^{1}$}

\section{A. Introduction}

1. This paper assesses medium- and long-term fiscal trends in Aruba. Aruba's fiscal position has been deteriorating since the turn of the century, and the medium-term fiscal sustainability analysis shows a continuous weakening ahead of population aging. The longterm projections, partly because of the weak starting fiscal position, indicate an even bigger problem. If immigration is stopped and labor productivity growth remains as low as in the past decade, the population will begin to age rapidly, and economic growth will drop to below $1 / 2$ percent a year by 2020 . This, combined with the consequent rapid increase in pension spending, will make public finances unsustainable.

\section{B. Recent Fiscal Developments}

2. Public debt has been increasing rapidly since 2000 (Figure 1). From about 281/2 percent of GDP in 1999-2000, public debt, including the health care fund (AZV) (hereafter, public debt), reached an estimated 45.9 percent of GDP at end-2004. Besides persistently high deficits, payments on guarantees, amounting to 6 percent of GDP (or $\$ 120$ million) in 2003, have also contributed to the rapid growth in public debt. ${ }^{2}$ To meet its financing needs, the government has increasingly resorted to foreign borrowing on commercial terms. The share of foreign debt at end-2004 is estimated to have reached almost 50 percent (Figure 2).

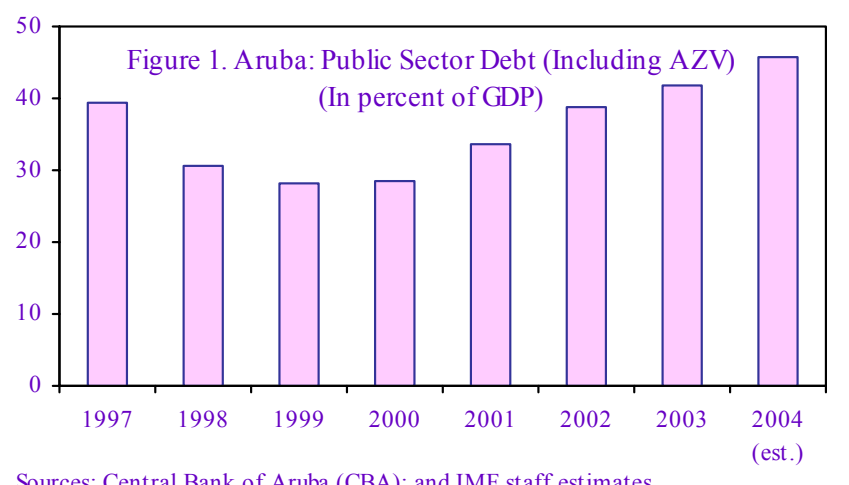

Sources: Central Bank of Aruba (CBA); and IMF staff estimates.

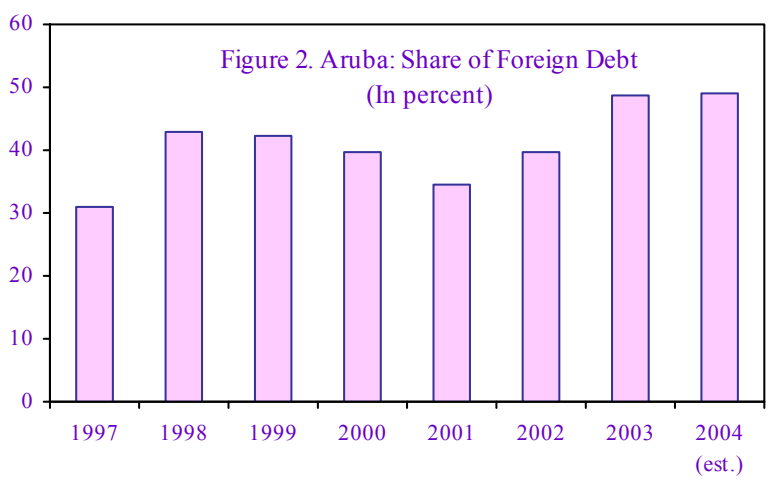

Sources: CBA; and IMF staff estimates.

\footnotetext{
${ }^{1}$ Prepared by Céline Allard.

${ }^{2}$ The stock of existing guarantees - previously issued to support the nascent tourism industry-is now close to zero, as the government stopped granting new guarantees to hotels in 1995; however, called guarantees under litigation still amounted to 3.6 percent of GDP at the end of 2004.
} 
3. The cost of public borrowing has been low but is likely to increase rapidly in the medium term. Though Aruba has a high income level, a significant part of its public debtfrom the European Investment Bank and the Netherlands - is still on concessional terms. Moreover, domestic state-owned public utilities lend at low rates to the government, and arrears that bear no interest reached about 8 percent of GDP in 2003. As a result, the effective average interest rate remained close to zero in real terms in 2003 (Figure 3). With a shift to commercial loans in external borrowing and the conversion of arrears into interestbearing loans, the interest charges started to increase in $2004 .^{3}$ A comparison with other similarly rated $(\mathrm{BBB})$ countries shows that interest costs are likely to rise further in the medium term as the share of public debt carrying commercial rates continues to increase (Table 1). In 2003, the average real interest rate paid on Aruba's public debt was -0.3 percent; the same rate reached 1.6 percent in Thailand and 4.7 percent in South Africa. This means that, had Aruba paid real interest rates equal to those of Thailand (South Africa), the interest payments would have amounted to 1.9 (3.1) percent of GDP, instead of the actual 1.2 percent of GDP.

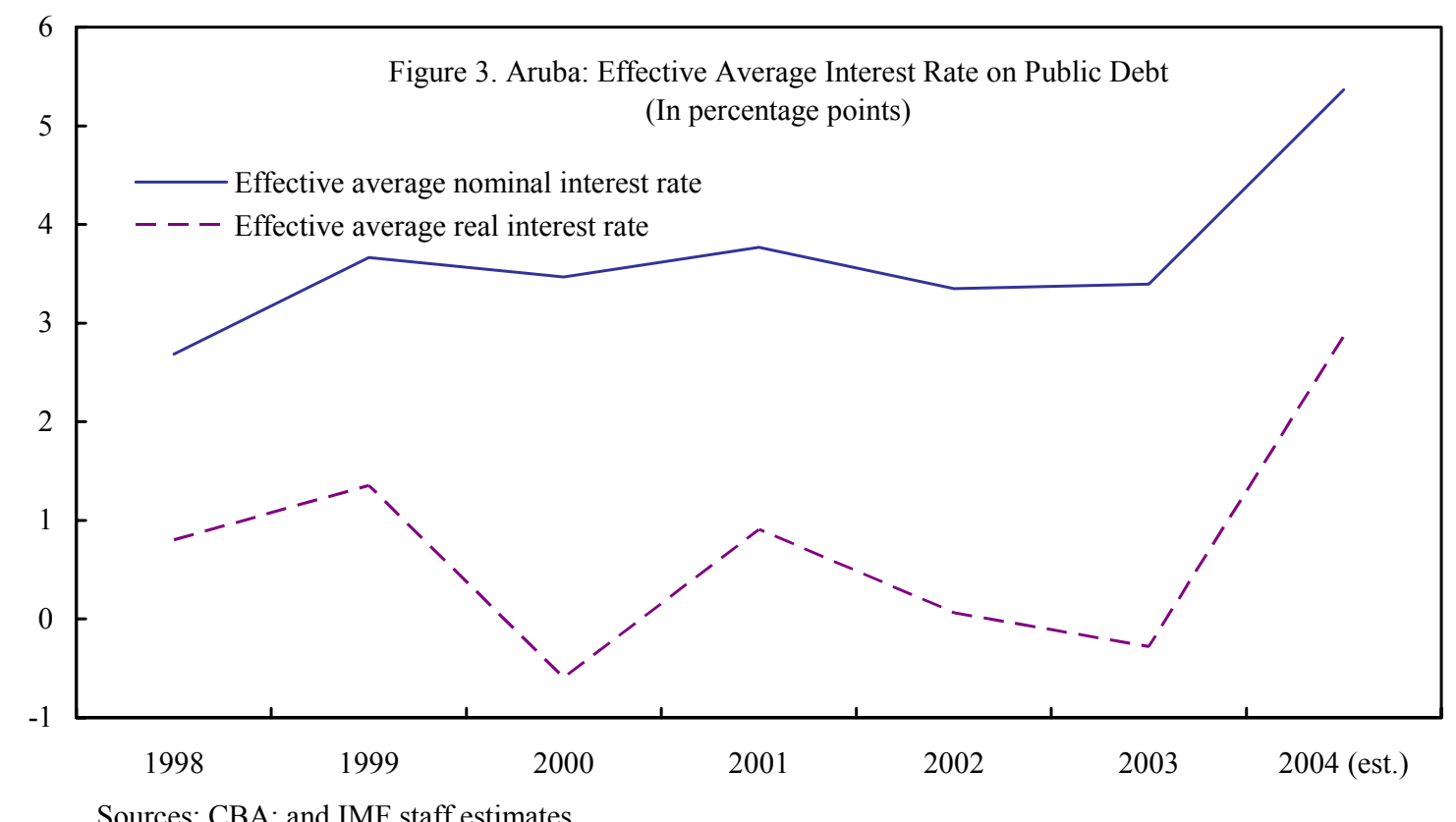

Sources: CBA; and IMF staff estimates.

\footnotetext{
${ }^{3}$ For example, in December 2004, all arrears by the government to the civil servant pension fund, APFA, (6.7 percent of GDP) were transformed into government loans and bonds with an interest rate of 6.7 percent in nominal terms.
} 
Table 1. Aruba: Comparison of Interest Payments with Other BBB-Rated Countries, 2003

\begin{tabular}{lrrr}
\hline & & \multicolumn{2}{c}{$\begin{array}{c}\text { Countries with Same } \\
\text { Rating (BBB) from Fitch }\end{array}$} \\
\cline { 3 - 4 } & Aruba & Thailand & South Africa \\
\hline Implicit nominal interest rate (percent) & 3.4 & 3.4 & 10.5 \\
Inflation (percent) & 3.7 & 1.8 & 5.8 \\
Implicit real interest rate (percent) & -0.3 & 1.6 & 4.7 \\
Actual interest payments in 2003 (in percent of GDP) & 1.2 & & \\
Aruba's interest costs assuming the real interest rates & & & \\
$\quad$ of Thailand or South Africa in 2003 (in percent of GDP) & & 1.9 & 3.1 \\
\hline
\end{tabular}

Sources: CBA; IMF staff reports; and IMF staff calculations.

4. Aruba's vulnerability to large shocks and the sensitivity of its fiscal performance to economic fluctuations point to the need for a more conservative policy on debt accumulation. While Aruba's average growth and fiscal deficit over the cycle seem broadly similar to those of regions with similar income levels, like the euro area, the standard deviation is about three times higher (Table 2). Consequently, debt limits used in other countries, like the Maastricht criterion of 60 percent of GDP, to which the authorities frequently refer, are not applicable to Aruba.

Table 2. Aruba: GDP Growth Rate and Public Deficit for Aruba and the Euro Area

\begin{tabular}{|c|c|c|c|c|}
\hline & $\begin{array}{r}\text { Peak } \\
\text { of Cycle }\end{array}$ & $\begin{array}{l}\text { Bottom } \\
\text { of Cycle }\end{array}$ & Average & $\begin{array}{r}\text { Standard } \\
\text { Deviation }\end{array}$ \\
\hline \multicolumn{5}{|c|}{ GDP growth rate (in percent) } \\
\hline \multirow[t]{2}{*}{ Aruba } & 1997 & $\underline{2002}$ & \multicolumn{2}{|c|}{$1997-2003$} \\
\hline & 7.8 & $\overline{-2.5}$ & 2.5 & 3.8 \\
\hline Euro area & $\frac{2000}{3.5}$ & $\frac{2003}{0.5}$ & 2.1 & 1.1 \\
\hline \multicolumn{5}{|c|}{ Fiscal deficit (in percent of GDP) } \\
\hline \multirow[t]{2}{*}{ Aruba } & 1998 & 2001 & \multicolumn{2}{|c|}{$1997-2003$} \\
\hline & $\overline{1.0}$ & $\overline{-4.1}$ & -1.8 & 2.1 \\
\hline \multirow[t]{2}{*}{ Euro area } & 2000 & 2003 & \multicolumn{2}{|c|}{$1998-2003$} \\
\hline & -0.9 & -2.8 & -1.9 & 0.7 \\
\hline
\end{tabular}

Sources: CBA; IMF staff reports; and IMF staff calculations. 


\section{Medium-Term Fiscal Trends}

5. Under unchanged policies, public debt is projected to increase rapidly in the medium term. ${ }^{4}$ Reflecting increasing borrowing costs, the overall deficit is set to widen further, from $5 \frac{1}{4}$ percent of GDP in 2005 to $6 \frac{1}{2}$ percent in 2009 . As a result, public debt is projected to soar to over 60 percent of GDP in 2009, from about 42 percent in 2003 (Table 3).

Table 3. Aruba: Medium-Term Fiscal Framework Under Unchanged Policies

(In percent of GDP)

\begin{tabular}{lrrrrrrr}
\hline Unchanged policies & 2003 & 2004 & 2005 & 2006 & 2007 & 2008 & 2009 \\
\hline Revenues & 22.3 & 22.2 & 21.9 & 21.6 & 21.5 & 21.4 & 21.3 \\
Expenditures & 25.0 & 26.6 & 26.2 & 26.3 & 26.5 & 26.7 & 27.0 \\
$\quad$ Current noninterest expenditure & 22.5 & 23.2 & 22.6 & 22.5 & 22.3 & 22.2 & 22.1 \\
Interest & 1.2 & 1.7 & 2.0 & 2.2 & 2.5 & 2.9 & 3.3 \\
Capital expenditure & 1.2 & 1.7 & 1.7 & 1.6 & 1.6 & 1.6 & 1.6 \\
Central government balance & -2.6 & -4.4 & -4.4 & -4.7 & -5.0 & -5.3 & -5.6 \\
AZV balance & -0.9 & -1.0 & -0.9 & -0.9 & -0.9 & -0.9 & -0.9 \\
Balance, including AZV & -3.5 & -5.5 & -5.2 & -5.6 & -5.8 & -6.2 & -6.5 \\
Debt & 41.7 & 45.9 & 48.6 & 51.6 & 54.6 & 58.1 & 61.7 \\
\hline
\end{tabular}

Sources: CBA; and IMF staff projections.

6. The results for alternative scenarios reveal major vulnerabilities (Figure 4):

- The most important risk appears to stem from real shocks. Assuming that GDP growth is lowered to -4.7 percent per year in $2005-06$, two standard deviations below the historical average, debt is projected to reach 90 percent of GDP by 2009 (Table 4).

- A recession similar to the one Aruba experienced in 2001-02 would also substantially increase public debt. In this scenario, (i) the growth rate is assumed to drop by one standard deviation in 2005-06 (to -0.3 percent in 2005 and -1.2 percent in 2006) $;^{5}$ (ii) as in 2001, the revenue-to-GDP ratio is assumed to drop by 1 percentage point for two years and to recover by only $1 / 2$ percentage point afterward, as the result of tax base erosion; and (iii) interest rates are permanently higher by 200 basis points, reflecting the increase in risk premium likely to be requested by foreign investors in such circumstances. Under these

\footnotetext{
${ }^{4}$ The assumptions underlying this central scenario include a stable tax revenue ratio, the disbursement of Dutch grants according to the schedule agreed upon with the authorities, current spending in line with GDP, stable capital spending, a marginal improvement in the AZV deficit, and a gradual increase of interest rates to international levels.

${ }^{5}$ In the 2001-02 recession, Aruba recorded growth rates of -0.7 percent in 2001 and -2.6 percent in 2002.
} 
assumptions, debt would reach 77 percent of GDP in 2009, some 16 percentage points higher than in the baseline scenario (Figure 4).

Table 4. Aruba: Bounds Test Analysis

\begin{tabular}{|c|c|c|c|c|c|}
\hline & \multicolumn{3}{|c|}{ Average 2004-09 } & & \\
\hline & \multirow{3}{*}{$\begin{array}{r}\begin{array}{r}\text { Real interest } \\
\text { Rate }\end{array} \\
\text { (In per }\end{array}$} & \multicolumn{2}{|c|}{ Real GDP Primary Deficit } & \multirow{2}{*}{\multicolumn{2}{|c|}{ Debt (in percent of GDP) }} \\
\hline & & Growth & \multirow{2}{*}{$\begin{array}{r}\text { (In percent } \\
\text { of GDP) }\end{array}$} & & \\
\hline & & ent) & & In 2004 & In 2009 \\
\hline Average 1997-2003 & 0.4 & 2.3 & 0.8 & & \\
\hline Baseline scenario & 2.3 & 2.7 & 3.3 & 45.9 & 61.7 \\
\hline \multicolumn{6}{|l|}{ Alternative scenarios } \\
\hline Interest rate shock $1 /$ & 2.2 & 2.7 & 3.3 & 45.9 & 61.7 \\
\hline Growth rate shock 2/ & 2.3 & 0.2 & 6.4 & 45.9 & 88.1 \\
\hline Fiscal shock 2/ & 2.3 & 2.7 & 3.9 & 45.9 & 64.9 \\
\hline Combination of three shocks 3 / & 2.0 & 1.4 & 3.2 & 45.9 & 63.9 \\
\hline \multicolumn{6}{|l|}{ All called guarantees still under } \\
\hline litigation become payable in 2005 & 2.3 & 2.7 & 3.3 & 45.9 & 65.3 \\
\hline
\end{tabular}

Sources: CBA; and IMF staff estimates.

1/ Historical average (over 1997-2003) plus two standard deviations in 2005-06.

2/ Historical average (over 1997-2003) minus two standard deviations in 2005-06. The primary balance is the variable modified in the fiscal shock.

3/ Historical average is augmented or decreased by only one standard deviation.

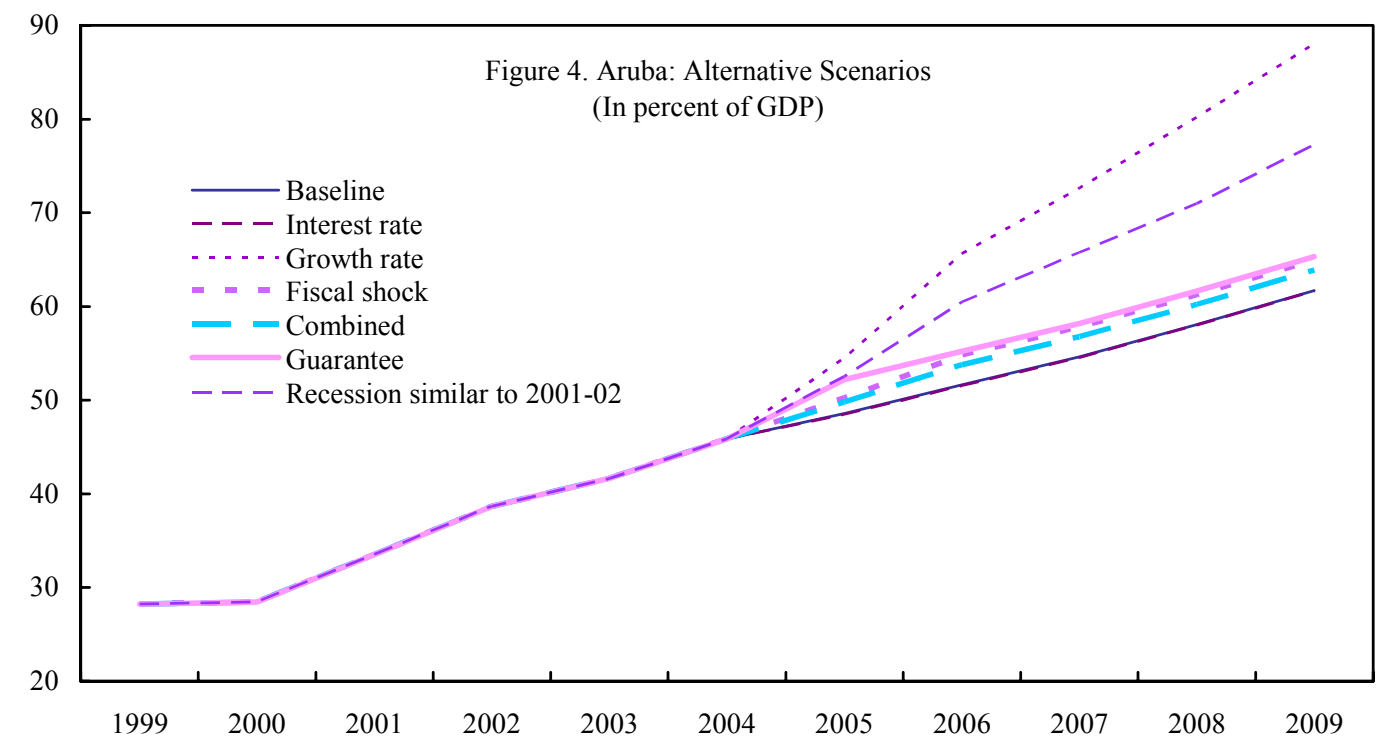

Source: IMF projections.

\section{Long-Term Fiscal Trends and the Impact of Aging}

7. The rapid population growth of the 1990s may not be sustainable in the future. Since it gained status aparte in 1986, Aruba has relied on immigration to meet the labor 
demand in its booming tourism industry. The resulting increase in population (from 66,700 in 1991 to 90,500 in 2000 and 95,000 in 2003) made Aruba the second most densely populated island in the Caribbean (after Barbados), leading to problems in the housing market and in the provision of water, electricity, and telecommunications. ${ }^{6}$ The government tightened its immigration legislation in June 2002 and intends to rely more on short-term foreign contractors while phasing out permanent immigration.

8. If immigration is halted, however, Aruba's population will age rapidly over the next 25 years. Extending population projections of the CBS, which assume zero net immigration and run until 2016, and using mortality and fertility rates derived from the 2000 census, staff projects the share of old people (above 60 years old) in the total population to double over the next 25 years, from 11-12 percent currently to 22 percent in $2030 .^{7}$ As a result, the dependency ratio ${ }^{8}$ of the pay-as-you-go pension fund would drop from 5.7 in 2005 to 2.7 in 2030 (Table 5).

Table 5. Aruba: Population Projections to 2030

Under the No-Immigration Assumption

\begin{tabular}{rrrrrrr}
\hline & Total & \multicolumn{2}{c}{ Share in Total Population (In percent) } & & Dependency Ratio \\
\cline { 3 - 4 } Year & Population & Age 0-15 & Age 16-59 & Age 60 \& over & (In percent) \\
\hline 2001 & 91,871 & 22.7 & 66.3 & 11.0 & 6.0 \\
2003 & 95,033 & 21.6 & 67.1 & 11.2 & 6.0 \\
2004 & 95,288 & 21.4 & 67.0 & 11.5 & 5.8 \\
2005 & 95,543 & 21.2 & 67.0 & 11.8 & 5.7 \\
2009 & 97,046 & 20.0 & 66.7 & 13.3 & 5.0 \\
2011 & 97,878 & 19.3 & 66.6 & 14.1 & 4.7 \\
2016 & 99,428 & 18.0 & 65.0 & 16.9 & 3.8 \\
2021 & 98,670 & 18.2 & 62.7 & 19.1 & 3.3 \\
2026 & 97,323 & 18.4 & 59.9 & 21.6 & 2.8 \\
2030 & 95,830 & 18.7 & 59.1 & 22.1 & 2.7 \\
\hline
\end{tabular}

Sources: CBS; and IMF staff projections.

9. The projected decline in the labor force, combined with the existing productivity trends, would slow economic growth dramatically in the long run. Over 1991-2000, despite a solid average growth rate of 4.9 percent, labor productivity increased by only 0.9 percent annually, reflecting the large share of the tourism industry, where the labor force is predominantly low-skilled. Assuming an unchanged economic structure and the projected

\footnotetext{
${ }^{6}$ Central Bureau of Statistics (CBS) of Aruba, 2002, "The People of Aruba, Continuity and Changes" (Census 2000 Special Reports, February).

${ }^{7}$ The recent waves of immigrants were concentrated in the early-working-age cohort. This large generation, now in its 30 s to early 40 s, will retire over the next 25 years.

${ }^{8}$ The dependency ratio is the ratio of contributors to beneficiaries.
} 
decline in the labor force, annual growth rates are projected to drop to about $3 / 4$ percent in 2015 , close to 0 in 2020 , and to $1 / 4$ percent afterward.

10. With such population and growth trends, the financial position of the universal pension system would deteriorate significantly in the long run. Aruba's General Old Age Pension Scheme (AOV), a pay-as-you-go system, provides flat benefits to all citizens over the age of 60 that currently amount to about 25 percent of per-worker GDP. ${ }^{9}$ The contribution rate is 13.5 percent, but insurable earnings are capped, resulting in an average effective rate on the overall payroll of just below 5 percent. Assuming that pension benefits are indexed to inflation plus half of the labor productivity gains, and assuming no change in the pension legislation, AOV's current surplus would turn into deficit by 2009 and would reach 3 percent of GDP by the second half of the 2020s (Figure 5).

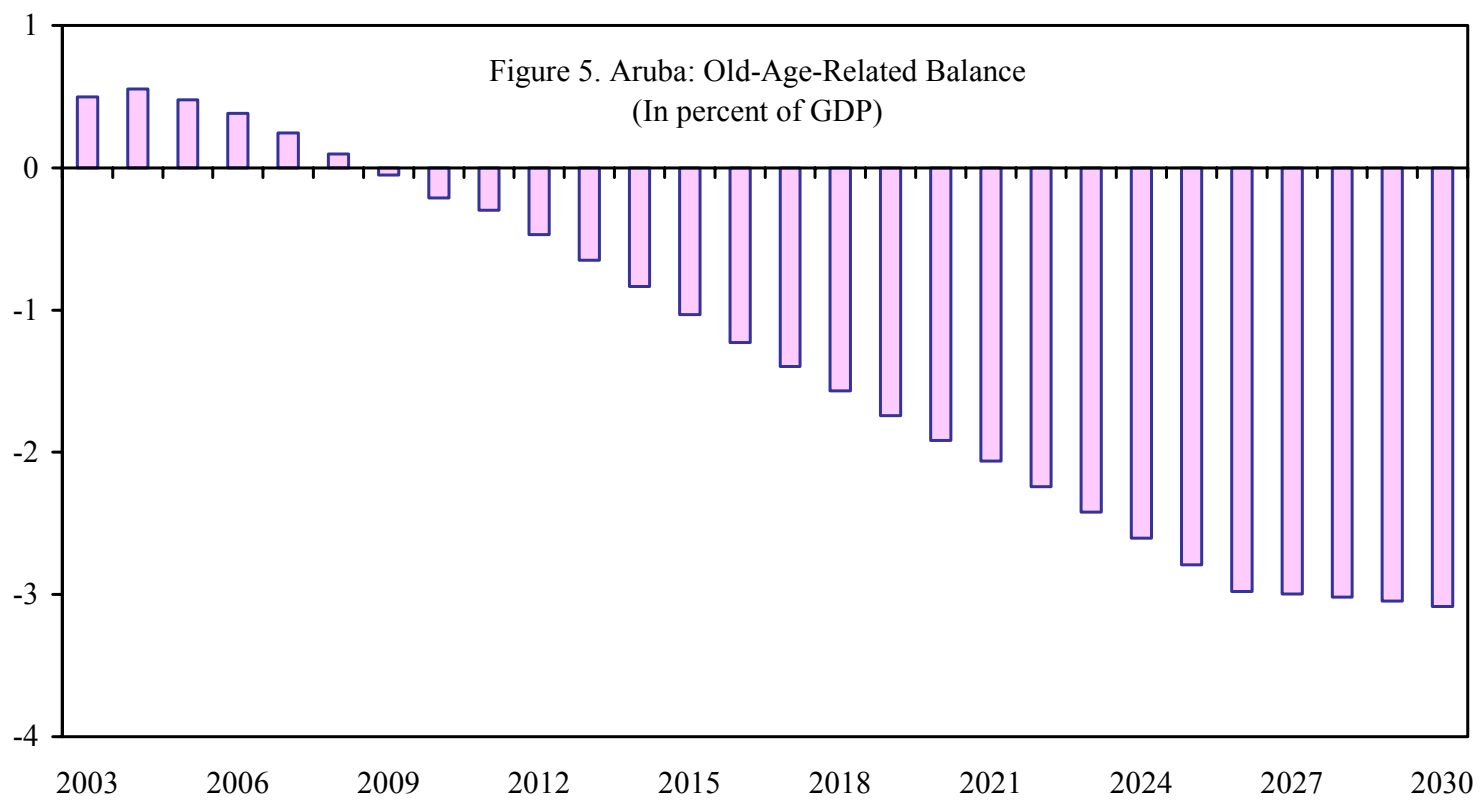

Sources: Aruba Social Insurance Bank (SVB); and IMF staff calculations.

11. In the absence of corrective measures, this would lead to an escalation of public debt over the next 25 years (Table 6 and Figures 6 and 7). Beyond the medium-term horizon previously discussed, the additional 3 percent or so of old-age-related spending would put public finances on an unsustainable path, and the explosion of both interest costs and debt would make a sharp adjustment in the fiscal position inevitable.

\footnotetext{
${ }^{9}$ This system is complemented by the General Widows and Orphans Insurance (AWW) — much smaller, but governed by the same principles.
} 
Table 6. Aruba: Long-Term Public Debt Sustainability Exercise, 2004-30

(In percent of GDP; unless stated otherwise)

\begin{tabular}{|c|c|c|c|c|c|c|}
\hline & 2004 & 2009 & 2015 & 2020 & 2025 & 2030 \\
\hline Public sector debt & 45.9 & 61.7 & 90.9 & 132.3 & 185.8 & 253.4 \\
\hline Public sector balance & -5.5 & -6.5 & -9.5 & -13.1 & -17.5 & -22.4 \\
\hline Interest payments & 1.7 & 3.3 & 5.3 & 7.7 & 10.9 & 15.0 \\
\hline Public sector primary balance & -3.8 & -3.2 & -4.3 & -5.4 & -6.6 & -7.4 \\
\hline Of which: balance related to aging & 0.6 & -0.1 & -1.0 & -1.9 & -2.8 & -3.1 \\
\hline \multicolumn{7}{|l|}{ Memorandum items: } \\
\hline Population (number of inhabitants) & 95,288 & 97,046 & 99,118 & 98,822 & 97,592 & 95,830 \\
\hline Ratio of active persons per pensioners & 5.8 & 5.0 & 4.0 & 3.4 & 2.9 & 2.7 \\
\hline Real GDP growth (in percent) & 3.5 & 2.1 & 0.8 & 0.1 & 0.3 & 0.2 \\
\hline Inflation (in percent) & 2.5 & 3.0 & 3.0 & 3.0 & 3.0 & 3.0 \\
\hline
\end{tabular}

Sources: SVB; CBA; and IMF staff estimates.
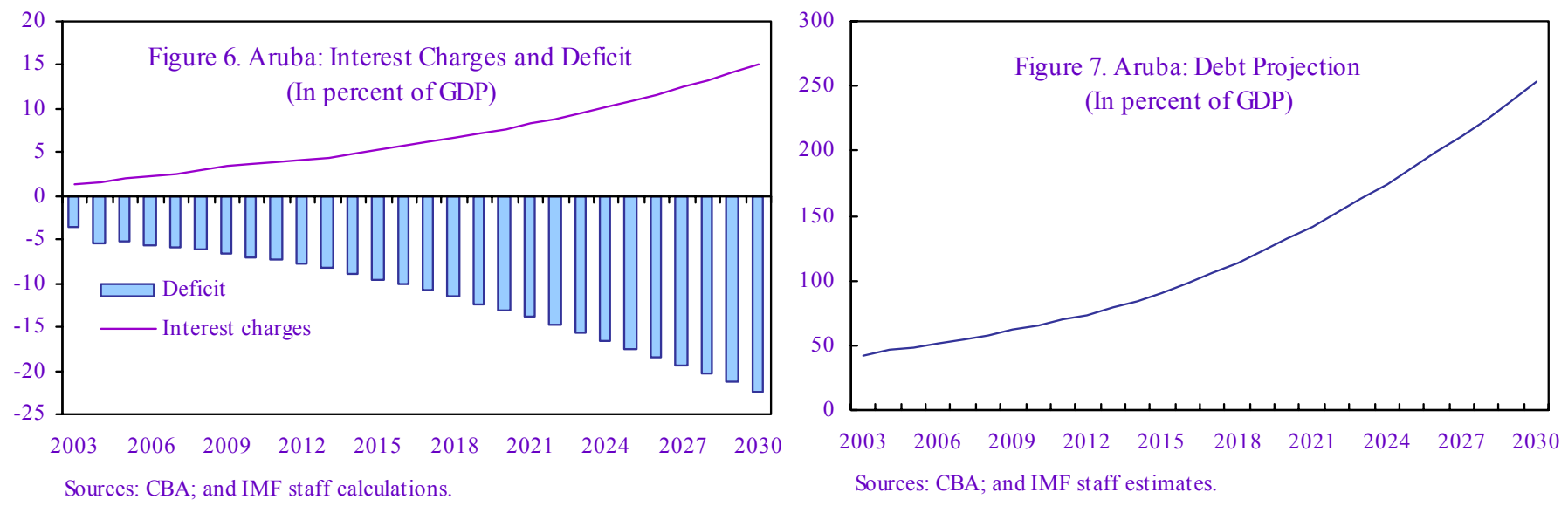

\section{Given the magnitude of the problem, measures will need to be taken on all fronts}

to bring public finances under control. Increasing productivity growth by 1 percentage point (more than doubling it), would still leave public debt above 200 percent of GDP by 2030 . Doubling the effective pension contribution rate would only lower public debt in 2030 to 150 percent of GDP. Even the combination of these two measures would leave public debt above 100 percent of GDP in 2030. These results point to the critical importance of strengthening the fiscal position and lowering the public debt before the onset of population aging (Figure 8). 


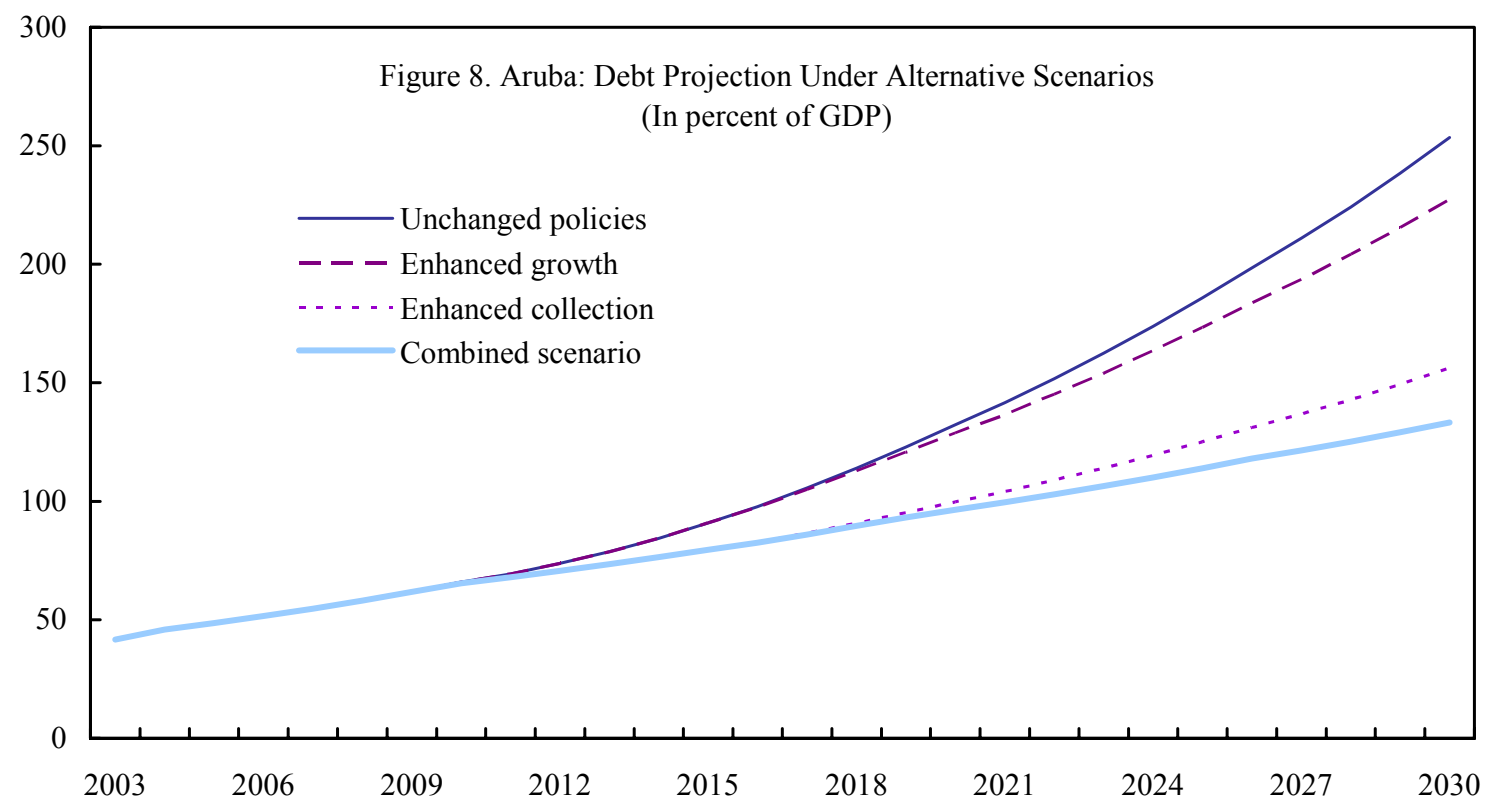

Sources: CBA; and IMF staff estimates.

E. Conclusion

13. Aruba's public finances are at a critical juncture. With unchanged policies, public debt is projected to continue to increase rapidly in the medium term. This would not only further increase fiscal vulnerabilities but also exacerbate the fiscal problems of upcoming population aging. To avoid this, an up-front and ambitious fiscal consolidation, significantly lowering the deficit and reducing the level of public debt, seems necessary.

14. In addition to medium-term fiscal consolidation, labor productivity will have to be raised and the pension legislation overhauled to ensure the stability of public finances in the long run. In order to foster labor productivity, the challenge will be to diversify the economy into higher-value-added activities. On the pension front, measures could include increasing the mandatory retirement age and expanding the contribution base. 
Table A1. Aruba: Indicators of Tourism Activity, 1995-2003

(In millions of Aruban florins at current prices; unless otherwise indicated)

\begin{tabular}{|c|c|c|c|c|c|c|c|c|c|}
\hline & 1995 & 1996 & 1997 & 1998 & 1999 & 2000 & 2001 & 2002 & 2003 \\
\hline Total revenue (Af. million) & 932 & 1,098 & 1,196 & 1,307 & 1,292 & 1,446 & 1,464 & 1,474 & 1,508 \\
\hline (Change in percent) & 11.2 & 17.8 & 8.9 & 9.3 & -1.1 & 11.9 & 1.2 & 0.7 & 2.3 \\
\hline (Change in percent, in real terms) & 7.6 & 14.2 & 5.8 & 7.2 & -3.3 & 7.6 & -1.6 & -2.5 & -1.3 \\
\hline Stay-over visitors (thousands) & 618.9 & 640.8 & 646.0 & 647.4 & 683.3 & 721.2 & 691.4 & 642.6 & 641.9 \\
\hline (Change in percent) & 6.5 & 3.5 & 0.8 & 0.2 & 5.5 & 5.5 & -4.1 & -7.1 & -0.1 \\
\hline Tourist nights (thousands) & 4,473 & 4,714 & 4,835 & 4,890 & 5,143 & 5,248 & 5,145 & 4,863 & 5,098 \\
\hline (Change in percent) & 5.7 & 5.4 & 2.6 & 1.1 & 5.2 & 2.0 & -2.0 & -5.5 & 4.8 \\
\hline Average stay (nights) & 7.2 & 7.4 & 7.5 & 7.6 & 7.5 & 7.3 & 7.4 & 7.6 & 7.9 \\
\hline $\begin{array}{l}\text { Expenditure per tourist per day } \\
\text { (in Aruban florins) }\end{array}$ & 208.3 & 233.0 & 247.4 & 267.3 & 251.2 & 275.5 & 284.6 & 303.1 & 295.8 \\
\hline Hotel occupancy rate (percent) & 72.0 & 71.5 & 73.4 & 77.6 & 77.0 & 75.9 & 75.6 & 71.7 & 74.4 \\
\hline Hotel capacity & 6,462 & 6,483 & 6,586 & 6,133 & 6,596 & 6,980 & 7,004 & 6,831 & 6,912 \\
\hline (Change in percent) & 8.0 & 0.3 & 1.6 & -6.9 & 7.5 & 5.8 & 0.3 & -2.5 & 1.2 \\
\hline Cruise tourists (thousands) & 294.0 & 316.7 & 297.7 & 257.8 & 289.1 & 490.0 & 487.3 & 582.2 & 542.3 \\
\hline (Change in percent) & 14.3 & 7.8 & -6.0 & -13.4 & 12.1 & 69.5 & -0.6 & 19.5 & -6.8 \\
\hline Contribution to foreign exchange earnings & 51.4 & 55.7 & 54.9 & 57.4 & 60.5 & 67.5 & 69.1 & 72.2 & 72.7 \\
\hline
\end{tabular}

Sources: CBA, Quarterly Bulletin; Aruba Tourism Authority; CBS; Aruba Hotel and Tourism Association; and the Cruise Tourism Authority. 
Table A2. Aruba: GDP and Components, 1995-2003

(In millions of Aruban florins at current prices)

\begin{tabular}{|c|c|c|c|c|c|c|c|c|c|}
\hline & 1995 & 1996 & 1997 & 1998 & 1999 & 2000 & 2001 & 2002 & 2003 \\
\hline Final consumption expenditure at purchasers' prices & 1,665 & 1,819 & 2,014 & 2,155 & 2,276 & 2,396 & 2,517 & 2,698 & 2,847 \\
\hline Household final consumption expenditure & 1,193 & 1,320 & 1,367 & 1,500 & 1,602 & 1,664 & 1,712 & 1,800 & 1,908 \\
\hline Government final consumption expenditure & 472 & 498 & 647 & 655 & 674 & 731 & 805 & 899 & 939 \\
\hline Gross capital formation & 736 & 703 & 830 & 945 & 952 & 818 & 763 & 798 & 985 \\
\hline Private gross fixed capital formation & 613 & 589 & 702 & 812 & 858 & 759 & 715 & 744 & 896 \\
\hline Public gross fixed capital formation & 56 & 58 & 71 & 40 & 41 & 28 & 28 & 22 & 50 \\
\hline Changes in inventories & 66 & 56 & 56 & 93 & 53 & 31 & 20 & 32 & 39 \\
\hline Exports of goods and services $1 /$ & 2,007 & 2,140 & 2,263 & 2,374 & 2,465 & 2,476 & 2,467 & 2,370 & 2,345 \\
\hline Exports of goods & 574 & 554 & 618 & 557 & 471 & 370 & 334 & 284 & 212 \\
\hline Tourism exports of goods and services & 1,024 & 1,097 & 1,159 & 1,210 & 1,292 & 1,443 & 1,459 & 1,327 & 1,332 \\
\hline Regular exports of services & 409 & 488 & 486 & 607 & 702 & 663 & 674 & 759 & 801 \\
\hline Imports of goods and services $1 /$ & 2,044 & 2,191 & 2,365 & 2,493 & 2,610 & 2,363 & 2,348 & 2,445 & 2,578 \\
\hline Imports of goods & 1,437 & 1,499 & 1,589 & 1,657 & 1,685 & 1,494 & 1,473 & 1,498 & 1,505 \\
\hline Imports of services & 607 & 692 & 776 & 836 & 925 & 868 & 875 & 948 & 1,073 \\
\hline Gross domestic product at market prices & 2,364 & 2,470 & 2,742 & 2,981 & 3,084 & 3,327 & 3,399 & 3,421 & 3,599 \\
\hline (Change in percent) & & 4.5 & 11.0 & 8.7 & 3.5 & 7.9 & 2.2 & 0.7 & 5.2 \\
\hline
\end{tabular}

Source: CBS, 2003 Estimates; CBA.

1/ The activities of the oil refinery are registered on a net basis, namely a refining fee is computed and used as the oil sector's output and export. Other goods and/or services imported or exported by the oil-sector are included in the trade figures.

Refinery products delivered to Aruban users are registered as import. 
Table A3. Aruba: Components in Percent of GDP, 1995-2003

(In percent)

\begin{tabular}{lrrrrrrrrr}
\hline & 1995 & 1996 & 1997 & 1998 & 1999 & 2000 & 2001 & 2002 & 2003 \\
\hline Gross domestic product & 100.0 & 100.0 & 100.0 & 100.0 & 100.0 & 100.0 & 100.0 & 100.0 & 100.0 \\
Private absorption & 79.3 & 79.5 & 77.5 & 80.7 & 81.5 & 73.8 & 72.0 & 75.3 & 79.0 \\
$\quad$ Consumption & 50.5 & 53.5 & 49.9 & 50.3 & 52.0 & 50.0 & 50.4 & 52.6 & 53.0 \\
Private investment 1/ & 28.8 & 26.1 & 27.6 & 30.4 & 29.5 & 23.7 & 21.6 & 22.7 & 26.0 \\
Government absorption & 22.3 & 22.6 & 26.2 & 23.3 & 23.2 & 22.8 & 24.5 & 26.9 & 27.5 \\
$\quad$ Consumption & 19.9 & 20.2 & 23.6 & 22.0 & 21.9 & 22.0 & 23.7 & 26.3 & 26.1 \\
$\quad$ Investment 2/ & 2.4 & 2.4 & 2.6 & 1.3 & 1.3 & 0.8 & 0.8 & 0.6 & 1.4 \\
Exports less imports 3/ & -1.6 & -2.1 & -3.7 & -4.0 & -4.7 & 3.4 & 3.5 & -2.2 & -6.5 \\
$\quad$ Goods & -26.4 & -28.1 & -25.6 & -27.7 & -29.3 & -23.6 & -23.7 & -26.9 & -27.7 \\
$\quad$ Services & 24.9 & 26.0 & 21.9 & 23.8 & 24.6 & 27.0 & 27.2 & 24.7 & 21.2 \\
\hline
\end{tabular}

Source: CBS.

1/ Private investment is equal to private gross fixed capital formation and private changes in inventories.

The investment of the oil sector is included in these figures.

2/ Public investment is equal to public gross fixed capital formation and public changes in inventories.

3/ Exports less imports of goods and services. The activities of the oil refinery are registered on a net basis, namely a refining fee is computed and used as the oil sector's output and export. Other goods and/or services imported or exported by the oil sector are included in the trade figures. Refinery products delivered to Aruban users are registered as import. 
Table A4. Aruba: Real GDP, 1996-2003

(In millions of Aruban florins at constant 1995 prices)

\begin{tabular}{lrrrrrrrr}
\hline & 1996 & 1997 & 1998 & 1999 & 2000 & 2001 & 2002 & 2003 \\
\hline Gross domestic product & $2,393.0$ & $2,579.2$ & $2,751.7$ & $2,783.8$ & $2,886.3$ & $2,866.3$ & $2,792.4$ & $2,836.2$ \\
$\quad$ Percent change) & 1.2 & 7.8 & 6.7 & 1.2 & 3.7 & -0.7 & -2.6 & 1.6 \\
Private absorption & $1,902.4$ & $1,998.8$ & $2,219.9$ & $2,269.0$ & $2,128.7$ & $2,064.0$ & $2,102.7$ & $2,240.4$ \\
$\quad$ Consumption & $1,279.3$ & $1,285.8$ & $1,384.4$ & $1,446.5$ & $1,443.8$ & $1,444.0$ & $1,469.0$ & $1,503.9$ \\
$\quad$ Private investment 1/ & 624.9 & 713.0 & 835.5 & 822.6 & 684.9 & 620.0 & 633.7 & 736.6 \\
Government absorption & 540.8 & 675.8 & 641.1 & 645.8 & 658.1 & 702.2 & 751.2 & 779.1 \\
$\quad$ Consumption & 483.4 & 608.7 & 605.4 & 609.7 & 635.0 & 679.3 & 734.4 & 739.7 \\
$\quad$ Investment 2/ & 57.4 & 67.1 & 35.8 & 36.2 & 23.1 & 22.9 & 16.8 & 39.4 \\
Exports less imports 3/ & & & & & & & \\
$\quad$ Goods & -50.3 & -95.4 & -110.1 & -130.8 & 98.1 & 100.3 & -61.4 & -183.3 \\
$\quad$ Services & -672.4 & -660.3 & -762.2 & -815.7 & -681.2 & -679.3 & -751.2 & -785.8 \\
\hline
\end{tabular}

Source: CBS.

$1 /$ Private investment is equal to private gross fixed capital formation and private changes in inventories. The investment of the oil sector is included in these figures.

2/ Public investment is equal to public gross fixed capital formation and public changes in inventories.

3/ Exports less imports of goods and services. The activities of the oil refinery are registered on a net basis, namely a refining fee is computed and used as the oil sector's output and export. Other goods and/or services imported or exported by the oil sector are included in the trade figures. Refinery products delivered to Aruban users are registered as import. 
Table A5. Aruba: Contributions to Real GDP Growth, 1996-2003

\begin{tabular}{|c|c|c|c|c|c|c|c|c|}
\hline & 1996 & 1997 & 1998 & 1999 & 2000 & 2001 & 2002 & 2003 \\
\hline Private absorption & 1.2 & 4.1 & 8.6 & 1.8 & -5.0 & -2.2 & 1.4 & 4.9 \\
\hline Consumption & 3.6 & 0.3 & 3.8 & 2.3 & -0.1 & 0.0 & 0.9 & 1.2 \\
\hline Private investment 1/ & -2.5 & 3.8 & 4.7 & -0.5 & -4.9 & -2.2 & 0.5 & 3.7 \\
\hline Government absorption & 0.6 & 5.6 & -1.3 & 0.2 & 0.4 & 1.5 & 1.7 & 1.0 \\
\hline Consumption & 0.5 & 5.2 & -0.1 & 0.2 & 0.9 & 1.5 & 1.9 & 0.2 \\
\hline Investment $2 /$ & 0.2 & 0.4 & -1.2 & 0.0 & -0.5 & 0.0 & -0.2 & 0.8 \\
\hline Exports less imports 3/ & -0.6 & -1.9 & -0.6 & -0.8 & 8.2 & 0.1 & -5.6 & -4.4 \\
\hline Goods & -2.0 & 0.5 & -4.0 & -1.9 & 4.8 & 0.1 & -2.5 & -1.2 \\
\hline Services & 1.4 & -2.4 & 3.5 & 1.1 & 3.4 & 0.0 & -3.1 & -3.1 \\
\hline Real GDP growth & 1.2 & 7.8 & 6.7 & 1.2 & 3.7 & -0.7 & -2.6 & 1.6 \\
\hline \multicolumn{9}{|l|}{ Memorandum item: } \\
\hline Nominal growth rate & 4.5 & 11.0 & 8.7 & 3.5 & 7.9 & 2.2 & 0.7 & 5.2 \\
\hline
\end{tabular}

Source: CBS.

1/ Private investment is equal to private gross fixed capital formation and private changes in inventories. The investment of the oil sector is included in these figures.

2/ Public investment is equal to public gross fixed capital formation and public changes in inventories.

3 / Exports less imports of goods and services. The activities of the oil refinery are registered on a net basis, namely a refining fee is computed and used as the oil sector's output and export. Other goods and/or services imported or exported by the oil sector are included in the trade figures. Refinery products delivered to Aruban users are registered as import. 
Table A6. Aruba: Changes in Consumer Price Index, 1996-2003

\begin{tabular}{|c|c|c|c|c|c|c|c|c|}
\hline & 1996 & 1997 & 1998 & 1999 & 2000 & 2001 & 2002 & 2003 \\
\hline Total & 3.2 & 3.0 & 1.9 & 2.3 & 4.1 & 2.9 & 3.3 & 3.7 \\
\hline Food & 4.0 & 3.1 & 2.0 & 2.1 & 1.8 & 3.3 & 3.3 & 3.1 \\
\hline Beverage and tobacco & 2.7 & 1.9 & 1.5 & 1.3 & 1.5 & -0.2 & 2.4 & 4.4 \\
\hline Clothing and footwear & 6.4 & 4.9 & 6.3 & 5.5 & 5.6 & 8.9 & 6.8 & 4.5 \\
\hline Housing costs & 1.5 & 5.0 & 0.8 & 2.0 & 8.1 & 2.3 & 4.1 & 5.7 \\
\hline Housekeeping and furnishings & 3.7 & 1.8 & 2.6 & 3.1 & 3.5 & 4.1 & 4.0 & 2.7 \\
\hline Recreation and education & 4.3 & 2.5 & 2.1 & 2.7 & 3.9 & 2.0 & 2.7 & 2.4 \\
\hline Miscellaneous & 1.8 & 2.1 & 1.5 & 1.7 & 3.0 & 2.8 & 2.5 & 2.6 \\
\hline Medical care & 6.6 & 2.1 & 0.5 & 0.3 & 0.4 & 0.1 & 0.0 & 0.0 \\
\hline Transport and communications & 1.8 & 1.6 & -0.1 & 0.6 & 3.1 & 0.3 & 0.9 & 2.8 \\
\hline United States & 2.9 & 2.3 & 1.6 & 2.2 & 3.4 & 2.8 & 1.6 & 2.3 \\
\hline Netherlands Antilles & 3.6 & 3.3 & 1.1 & 0.4 & 5.8 & 1.8 & 0.4 & 2.0 \\
\hline Core inflation & 2.5 & 2.1 & 2.0 & 1.9 & 2.7 & 3.0 & 2.9 & 2.5 \\
\hline
\end{tabular}

Sources: CBA, Quarterly Bulletin; and CBS.

Table A7. Aruba: Legal Minimum Wages, 1995-2004 1/

(In Aruban florins per month)

\begin{tabular}{lrrrrrrrrrr}
\hline & 1995 & 1996 & 1997 & 1998 & 1999 & 2000 & 2001 & 2002 & 2003 & $20042 /$ \\
\hline Category: & & & & & & & & & & \\
$\quad$ Construction and industry & 994.5 & $1,025.4$ & $1,060.2$ & $1,088.9$ & $1,111.8$ & $1,111.8$ & $1,111.8$ & $1,200.0$ & $1,200.0$ & $1,236.0$ \\
Household personnel & 460.0 & 478.4 & 494.7 & 508.1 & 518.8 & 560.0 & 560.0 & 560.0 & 560.0 & 576.8 \\
\hline
\end{tabular}

Source: Aruban Department of Labor.

1/ As of January 1st.

2/ As of July 1st. 
Table A8. Aruba: Summary of Trends in Public Finance, 1995-2003

\begin{tabular}{|c|c|c|c|c|c|c|c|c|c|}
\hline & 1995 & 1996 & 1997 & 1998 & 1999 & 2000 & 2001 & 2002 & 2003 \\
\hline Revenue & 602.7 & 645.3 & 627.6 & 646.5 & 701.6 & 742.2 & 731.8 & 751.2 & 803.5 \\
\hline Taxes & 458.6 & 491.6 & 499.7 & 535.5 & 608.7 & 624.5 & 606.3 & 610.0 & 687.4 \\
\hline Nontax revenue & 117.0 & 125.8 & 89.6 & 95.3 & 91.5 & 100.8 & 125.5 & 103.8 & 86.1 \\
\hline Grants & 27.1 & 27.9 & 38.3 & 15.7 & 1.4 & 16.9 & 0.0 & 37.4 & 30.1 \\
\hline Expenditure & 611.7 & 728.9 & 692.9 & 618.0 & 674.8 & 783.8 & 833.8 & 822.9 & 898.9 \\
\hline Current expenditure & $\ldots$ & $\ldots$ & 612.7 & 586.3 & 648.6 & 755.5 & 815.4 & 805.9 & 856.3 \\
\hline Wage costs & $\ldots$ & $\ldots$ & 344.4 & 339.8 & 354.1 & 416.1 & 446.5 & 473.3 & 465.9 \\
\hline Wages & $\ldots$ & $\ldots$ & 205.7 & 213.1 & 222.3 & 246.3 & 255.2 & 261.7 & 265.6 \\
\hline Employers contributions 1/ & $\ldots$ & $\ldots$ & 80.4 & 50.0 & 46.1 & 80.1 & 99.8 & 107.9 & 94.4 \\
\hline Wage subsidies & $\ldots$ & $\ldots$ & 58.3 & 76.8 & 85.6 & 89.7 & 91.5 & 103.7 & 105.9 \\
\hline Goods and services $2 /$ & $\ldots$ & $\ldots$ & 170.5 & 149.0 & 170.7 & 215.3 & 177.2 & 113.9 & 150.5 \\
\hline Interest & $\ldots$ & $\ldots$ & 23.9 & 29.0 & 33.4 & 30.2 & 35.7 & 38.2 & 44.9 \\
\hline Items not included elsewhere 3/ & $\ldots$ & $\ldots$ & 73.8 & 68.4 & 90.5 & 93.9 & 156.0 & 180.5 & 195.0 \\
\hline Capital expenditure & $\ldots$ & $\ldots$ & 80.2 & 31.8 & 26.2 & 28.3 & 18.4 & 17.0 & 42.6 \\
\hline Investment & $\ldots$ & $\ldots$ & 41.9 & 13.6 & 24.8 & 28.3 & 18 & 13.3 & 26.4 \\
\hline Capital transfers & $\ldots$ & $\ldots$ & 38.3 & 18.1 & 1.4 & 0.0 & 0 & 3.7 & 16.2 \\
\hline Balance 4/ & -9.0 & -83.6 & -65.3 & 28.5 & 26.8 & -41.6 & -102.0 & -71.7 & -95.3 \\
\hline Statistical discrepancy & 0.0 & 0.0 & -1.5 & 7.3 & 3.9 & -0.1 & 0.3 & 0.1 & 0.0 \\
\hline Financing & 9.0 & 83.6 & 63.7 & -21.2 & -22.9 & 41.5 & 102.3 & 71.7 & 95.3 \\
\hline Nonmonetary sectors & 35.5 & 28.1 & 15.0 & 17.0 & 2.8 & 7.3 & 42.1 & 98.5 & -20.0 \\
\hline Net foreign capital & 1.0 & -19.0 & -16.0 & 39.7 & 13.3 & 24.1 & 27.9 & 96.0 & -29.0 \\
\hline Loans received & 20.2 & 0.0 & 0.0 & 55.6 & 26.7 & 73.4 & 49.3 & 136.0 & 293.6 \\
\hline Repayments on loans received & 19.2 & 19.0 & 16.0 & 15.9 & 13.4 & 49.3 & 21.4 & 40.0 & 322.6 \\
\hline Net domestic capital & 34.5 & 47.1 & 31.0 & -22.7 & -10.5 & -16.8 & 14.2 & 2.5 & 9.0 \\
\hline Monetary sectors & -26.5 & 19.1 & 31.8 & 0.8 & 21.3 & -13.4 & -24.7 & -36.2 & 19.1 \\
\hline Net lending & $\ldots$ & $\ldots$ & 15.1 & 31.9 & 37.4 & 16.2 & 32.0 & -3.0 & -71.1 \\
\hline Change in domestic payment obligations 4 / & $\cdots$ & 36.4 & 32.0 & -7.1 & -9.6 & 63.8 & 116.9 & 6.4 & 25.1 \\
\hline \multicolumn{10}{|l|}{ Memorandum item: } \\
\hline Health care fund balance $5 /$ & $\ldots$ & $\ldots$ & $\ldots$ & $\ldots$ & $\ldots$ & $\cdots$ & -36.3 & -46.0 & -31.6 \\
\hline
\end{tabular}

Source: Data provided by the Aruban authorities.

1/ It includes arrears to the public employee pension fund (APFA) from 1997 and to the health care fund (AZV) from 2001.

2/ From 1997, it includes arrears to suppliers.

3/ Up to 1997, it includes net lending.

4/ For 1995, the change in payment arrears is not known. Hence, any spending financed by a change in arrears is not included in the balance. For 1996, change in domestic payment obligations excludes APFA arrears.

5/ The health care fund (AZV) was introduced in 2001. 
Table A9. Aruba: Summary of Trends in Public Finance, 1995-2003

(In percent of GDP)

\begin{tabular}{|c|c|c|c|c|c|c|c|c|c|}
\hline & 1995 & 1996 & 1997 & 1998 & 1999 & 2000 & 2001 & 2002 & 2003 \\
\hline Revenue & 25.5 & 26.1 & 22.9 & 21.7 & 22.8 & 22.3 & 21.5 & 22.0 & 22.3 \\
\hline Taxes & 19.4 & 19.9 & 18.2 & 18.0 & 19.7 & 18.8 & 17.8 & 17.8 & 19.1 \\
\hline Nontax revenue & 4.9 & 5.1 & 3.3 & 3.2 & 3.0 & 3.0 & 3.7 & 3.0 & 2.4 \\
\hline Grants & 1.1 & 1.1 & 1.4 & 0.5 & 0.0 & 0.5 & 0.0 & 1.1 & 0.8 \\
\hline Expenditure & 25.9 & 29.5 & 25.3 & 20.7 & 21.9 & 23.6 & 24.5 & 24.1 & 25.0 \\
\hline Current expenditure & $\ldots$ & $\ldots$ & 22.3 & 19.7 & 21.0 & 22.7 & 24.0 & 23.6 & 23.8 \\
\hline Wage costs & $\ldots$ & $\ldots$ & 12.6 & 11.4 & 11.5 & 12.5 & 13.1 & 13.8 & 12.9 \\
\hline Wages & $\ldots$ & $\ldots$ & 7.5 & 7.1 & 7.2 & 7.4 & 7.5 & 7.6 & 7.4 \\
\hline Employers contributions 1/ & $\ldots$ & $\ldots$ & 2.9 & 1.7 & 1.5 & 2.4 & 2.9 & 3.2 & 2.6 \\
\hline Wage subsidies & $\ldots$ & $\ldots$ & 2.1 & 2.6 & 2.8 & 2.7 & 2.7 & 3.0 & 2.9 \\
\hline Goods and services 2/ & $\ldots$ & $\ldots$ & 6.2 & 5.0 & 5.5 & 6.5 & 5.2 & 3.3 & 4.2 \\
\hline Interest & $\ldots$ & $\ldots$ & 0.9 & 1.0 & 1.1 & 0.9 & 1.1 & 1.1 & 1.2 \\
\hline Items not included elsewhere 3/ & $\ldots$ & $\ldots$ & 2.7 & 2.3 & 2.9 & 2.8 & 4.6 & 5.3 & 5.4 \\
\hline Capital expenditure & $\ldots$ & $\ldots$ & 2.9 & 1.1 & 0.8 & 0.9 & 0.5 & 0.5 & 1.2 \\
\hline Investment & $\ldots$ & $\ldots$ & 1.5 & 0.5 & 0.8 & 0.9 & 0.5 & 0.4 & 0.7 \\
\hline Capital transfers & $\ldots$ & $\ldots$ & 1.4 & 0.6 & 0.0 & 0.0 & 0.0 & 0.1 & 0.5 \\
\hline Balance 4/ & -0.4 & -3.4 & -2.4 & 1.0 & 0.9 & -1.3 & -3.0 & -2.1 & -2.6 \\
\hline Statistical discrepancy & 0.0 & 0.0 & -0.1 & 0.2 & 0.1 & 0.0 & 0.0 & 0.0 & 0.0 \\
\hline Financing & 0.4 & 3.4 & 2.3 & -0.7 & -0.7 & 1.2 & 3.0 & 2.1 & 2.6 \\
\hline Nonmonetary sectors & 1.5 & 1.1 & 0.5 & 0.6 & 0.1 & 0.2 & 1.2 & 2.9 & -0.6 \\
\hline Net foreign capital & 0.0 & -0.8 & -0.6 & 1.3 & 0.4 & 0.7 & 0.8 & 2.8 & -0.8 \\
\hline Loans received & 0.9 & 0.0 & 0.0 & 1.9 & 0.9 & 2.2 & 1.5 & 4.0 & 8.2 \\
\hline Repayments on loans received & 0.8 & 0.8 & 0.6 & 0.5 & 0.4 & 1.5 & 0.6 & 1.2 & 9.0 \\
\hline Net domestic capital & 1.5 & 1.9 & 1.1 & -0.8 & -0.3 & -0.5 & 0.4 & 0.1 & 0.3 \\
\hline Monetary sectors & -1.1 & 0.8 & 1.2 & 0.0 & 0.7 & -0.4 & -0.7 & -1.1 & 0.5 \\
\hline Net lending & $\ldots$ & $\ldots$ & 0.6 & 1.1 & 1.2 & 0.5 & 0.9 & -0.1 & -2.0 \\
\hline Change in domestic payment obligations 4 / & $\ldots$ & 1.5 & 1.2 & -0.2 & -0.3 & 1.9 & 3.4 & 0.2 & 0.7 \\
\hline \multicolumn{10}{|l|}{ Memorandum item: } \\
\hline Health care fund balance $5 /$ & $\ldots$ & $\ldots$ & $\ldots$ & $\ldots$ & $\ldots$ & $\ldots$ & -1.1 & -1.3 & -0.9 \\
\hline
\end{tabular}

Source: Data provided by the Aruban authorities.

1/ It includes arrears to the public employee pension fund (APFA) from 1997 and to the health care fund (AZV) from 2001. 2/ From 1997, it includes arrears to suppliers.

3/ Up to 1996, it includes net lending.

4/ For 1995, the change in payment arrears is not known. Any spending financed by a change in arrears is therefore not included in the balance. For 1996, change in domestic payment obligations excludes APFA arrears.

5/ The health care fund (AZV) was introduced in 2001. 
Table A10. Aruba: Tax Revenue, 1995-2003 1/

(In millions of Aruban florins)

\begin{tabular}{lrrrrrrrrr}
\hline & 1995 & 1996 & 1997 & 1998 & 1999 & 2000 & 2001 & 2002 & 2003 \\
\hline Taxes & 458.6 & 491.6 & 499.7 & 535.5 & 608.7 & 624.5 & 606.3 & 610.0 & 687.4 \\
Direct taxes & 258.7 & 277.3 & 283.6 & 310.9 & 372.3 & 371.0 & 368.5 & 370.7 & 424.4 \\
Wage taxes & 141.6 & 150.5 & 159.9 & 176.2 & 200.6 & 202.3 & 209.7 & 220.1 & 234.9 \\
Income taxes & 14.2 & 10.6 & 8.8 & 13.1 & 28.1 & 25.8 & 3.1 & 3.0 & -0.6 \\
Profit taxes & 54.7 & 61.9 & 62.8 & 62.0 & 80.1 & 81.4 & 90.0 & 78.3 & 105.6 \\
Solidarity tax & 0.6 & 0.3 & 0.1 & 0.3 & 0.2 & 0.0 & 0.0 & 0.0 & 0.0 \\
Other & 47.6 & 54.0 & 52.0 & 59.3 & 63.3 & 61.5 & 65.7 & 69.4 & 84.5 \\
$\quad$ Land tax & 8.1 & 8.8 & 9.4 & 12.1 & 14.7 & 11.6 & 9.7 & 12.3 & 27.5 \\
$\quad$ Hotel room taxes & 14.9 & 19.0 & 17.4 & 18.8 & 19.3 & 21.9 & 26.6 & 24.8 & 25.1 \\
$\quad$ Gambling taxes & 14.9 & 15.7 & 14.5 & 15.2 & 17.5 & 15.2 & 16.1 & 17.1 & 17.2 \\
$\quad$ Motor vehicle taxes & 9.7 & 10.5 & 10.7 & 13.2 & 11.8 & 12.8 & 13.3 & 15.2 & 14.7 \\
Indirect taxes & & & & & & & & & \\
Excises & 199.9 & 214.3 & 216.1 & 224.6 & 236.4 & 253.5 & 237.8 & 239.3 & 263.0 \\
$\quad$ Gasoline & 94.3 & 92.3 & 95.4 & 98.9 & 100.6 & 106.5 & 104.6 & 109.0 & 119.5 \\
Tobacco & 56.0 & 54.8 & 54.9 & 58.4 & 59.9 & 62.6 & 62.2 & 65.2 & 68.7 \\
Beer & 10.2 & 9.7 & 9.8 & 9.9 & 10.4 & 11.4 & 9.8 & 10.4 & 12.6 \\
$\quad$ Liquor & 18.9 & 17.7 & 19.7 & 20.1 & 19.3 & 20.3 & 19.4 & 20.3 & 24.3 \\
Import duties & 9.2 & 10.1 & 11.0 & 10.5 & 11.0 & 12.2 & 13.2 & 13.1 & 13.9 \\
Foreign exchange tax & 77.5 & 87.3 & 88.1 & 88.8 & 97.4 & 106.1 & 98.0 & 104.5 & 114.9 \\
Other taxes 2/ & 17.2 & 15.8 & 16.8 & 20.2 & 21.6 & 23.6 & 24.8 & 14.4 & 14.0 \\
\hline
\end{tabular}

Source: Ministry of Finance, Tax Department.

1/ Cash basis.

2/ Includes property transfer tax, stamp duties, and succession tax. 
Table A11. Aruba: Tax Revenue, 1995-2003 1/

(In percent of GDP)

\begin{tabular}{lrrrrrrrrr}
\hline & 1995 & 1996 & 1997 & 1998 & 1999 & 2000 & 2001 & 2002 & 2003 \\
\hline Taxes & 19.4 & 19.9 & 18.2 & 18.0 & 19.7 & 18.8 & 17.8 & 17.8 & 19.1 \\
Direct taxes & 10.9 & 11.2 & 10.3 & 10.4 & 12.1 & 11.2 & 10.8 & 10.8 & 11.8 \\
Wage taxes & 6.0 & 6.1 & 5.8 & 5.9 & 6.5 & 6.1 & 6.2 & 6.4 & 6.5 \\
Income taxes & 0.6 & 0.4 & 0.3 & 0.4 & 0.9 & 0.8 & 0.1 & 0.1 & 0.0 \\
Profit taxes & 2.3 & 2.5 & 2.3 & 2.1 & 2.6 & 2.4 & 2.6 & 2.3 & 2.9 \\
Solidarity tax & 0.0 & 0.0 & 0.0 & 0.0 & 0.0 & 0.0 & 0.0 & 0.0 & 0.0 \\
Other & 2.0 & 2.2 & 1.9 & 2.0 & 2.1 & 1.8 & 1.9 & 2.0 & 2.3 \\
Land tax & 0.3 & 0.4 & 0.3 & 0.4 & 0.5 & 0.3 & 0.3 & 0.4 & 0.8 \\
Hotel room taxes & 0.6 & 0.8 & 0.6 & 0.6 & 0.6 & 0.7 & 0.8 & 0.7 & 0.7 \\
Gambling taxes & 0.6 & 0.6 & 0.5 & 0.5 & 0.6 & 0.5 & 0.5 & 0.5 & 0.5 \\
Motor vehicle taxes & 0.4 & 0.4 & 0.4 & 0.4 & 0.4 & 0.4 & 0.4 & 0.4 & 0.4 \\
Indirect taxes & 8.5 & 8.7 & 7.9 & 7.5 & 7.7 & 7.6 & 7.0 & 7.0 & 7.3 \\
Excises & 4.0 & 3.7 & 3.5 & 3.3 & 3.3 & 3.2 & 3.1 & 3.2 & 3.3 \\
Gasoline & 2.4 & 2.2 & 2.0 & 2.0 & 1.9 & 1.9 & 1.8 & 1.9 & 1.9 \\
Tobacco & 0.4 & 0.4 & 0.4 & 0.3 & 0.3 & 0.3 & 0.3 & 0.3 & 0.4 \\
Beer & 0.8 & 0.7 & 0.7 & 0.7 & 0.6 & 0.6 & 0.6 & 0.6 & 0.7 \\
Liquor & 0.4 & 0.4 & 0.4 & 0.4 & 0.4 & 0.4 & 0.4 & 0.4 & 0.4 \\
Import duties & 3.3 & 3.5 & 3.2 & 3.0 & 3.2 & 3.2 & 2.9 & 3.1 & 3.2 \\
Foreign exchange tax & 0.7 & 0.6 & 0.6 & 0.7 & 0.7 & 0.7 & 0.7 & 0.4 & 0.4 \\
Other taxes 2/ & 0.5 & 0.8 & 0.6 & 0.6 & 0.5 & 0.5 & 0.3 & 0.3 & 0.4 \\
\hline
\end{tabular}

Source: Ministry of Finance, Tax Department.

$1 /$ Cash basis.

2/ Includes property transfer tax and stamp duties. 
Table A12. Aruba: Operational Budget of the Social Insurance Bank (SVB), 1996-2003

\begin{tabular}{|c|c|c|c|c|c|c|c|c|}
\hline & 1996 & 1997 & 1998 & 1999 & 2000 & 2001 & 2002 & 2003 \\
\hline & \multicolumn{8}{|c|}{ (In millions of Aruban florins) } \\
\hline Total contributions & 162.7 & 177.4 & 179.6 & 198.2 & 190.1 & 172.2 & 180.7 & 198.9 \\
\hline Total benefits & 152.4 & 165.1 & 180.7 & 178.0 & 188.1 & 152.0 & 152.0 & 157.2 \\
\hline Administrative and interest costs & 12.7 & 13.3 & 13.6 & 12.9 & 7.6 & 8.9 & 11.5 & 12.0 \\
\hline Administrative costs & 9.5 & 9.9 & 10.4 & 9.4 & 8.8 & $\ldots$ & 9.3 & 9.5 \\
\hline Interest costs & 3.2 & 3.4 & 3.2 & 3.5 & -1.2 & $\ldots$ & 2.2 & 2.5 \\
\hline Overall balance & -2.3 & -0.9 & -14.7 & 7.3 & -5.6 & 11.3 & 17.3 & 29.6 \\
\hline \multicolumn{9}{|l|}{ Old age and widowers and orphans insurance } \\
\hline Contributions & 110.7 & 122.1 & 113.6 & 134.6 & 139.7 & 149.5 & 150.2 & 158.9 \\
\hline Benefits & 104.1 & 110.1 & 118.8 & 120.7 & 125.5 & 135.7 & 136.7 & 138.4 \\
\hline Administrative and interest costs & 3.3 & 3.4 & 3.2 & 3.0 & -1.7 & 2.3 & 1.6 & 2.6 \\
\hline Administrative costs & 1.5 & 1.6 & 1.9 & 2.1 & 2.2 & $\ldots$ & 2.4 & 2.7 \\
\hline Interest costs & 1.8 & 1.8 & 1.3 & 0.9 & -3.9 & $\ldots$ & -0.8 & -0.1 \\
\hline Balance & 3.3 & 8.6 & -8.5 & 10.9 & 15.8 & 11.5 & 11.9 & 17.9 \\
\hline \multicolumn{9}{|l|}{ Sickness and accident insurance } \\
\hline Contributions & 50.8 & 54.0 & 65.8 & 62.2 & 49.7 & 20.2 & 29.9 & 39.1 \\
\hline Benefits & 47.8 & 54.7 & 61.4 & 56.4 & 61.2 & 15.5 & 14.7 & 18.5 \\
\hline Administrative and interest costs & 9.8 & 10.3 & 10.9 & 10.6 & 9.6 & 6.3 & 10.4 & 9.9 \\
\hline Administrative costs & 7.9 & 8.2 & 8.5 & 7.5 & 6.3 & 0.0 & 6.5 & 6.4 \\
\hline Interest costs & 1.9 & 2.1 & 2.4 & 3.1 & 3.3 & 0.0 & 3.9 & 3.5 \\
\hline Balance & -6.8 & -11.0 & -6.5 & -4.8 & -21.1 & -1.6 & 4.8 & 10.7 \\
\hline \multicolumn{9}{|l|}{ Severance insurance } \\
\hline Contributions & 1.3 & 1.4 & 0.2 & 1.4 & 0.7 & 1.6 & 0.6 & 0.9 \\
\hline Interest revenues & 0.5 & 0.5 & 0.6 & 0.5 & 0.7 & 0.9 & 0.9 & 0.9 \\
\hline Benefits & 0.4 & 0.3 & 0.4 & 0.9 & 1.4 & 0.8 & 0.6 & 0.3 \\
\hline Administrative costs & 0.1 & 0.1 & 0.1 & 0.1 & 0.3 & 0.3 & 0.4 & 0.4 \\
\hline \multirow[t]{2}{*}{ Balance } & 1.3 & 1.5 & 0.3 & 0.9 & -0.3 & 1.4 & 0.6 & 1.0 \\
\hline & \multicolumn{8}{|c|}{ (Overall balances in percent of GDP) } \\
\hline Total contributions & 6.6 & 6.5 & 6.0 & 6.4 & 5.7 & 5.1 & 5.3 & 5.5 \\
\hline Total benefits & 6.2 & 6.0 & 6.1 & 5.8 & 5.7 & 4.5 & 4.4 & 4.4 \\
\hline Administrative and interest costs & 0.5 & 0.5 & 0.5 & 0.4 & 0.2 & 0.3 & 0.3 & 0.3 \\
\hline Administrative costs & 0.4 & 0.4 & 0.4 & 0.3 & 0.3 & $\ldots$ & 0.3 & 0.3 \\
\hline Interest costs & 0.1 & 0.1 & 0.1 & 0.1 & 0.0 & $\ldots$ & 0.1 & 0.1 \\
\hline Overall balance & -0.1 & 0.0 & -0.5 & 0.2 & -0.2 & 0.3 & 0.5 & 0.8 \\
\hline \multicolumn{9}{|l|}{ Old age and widowers and orphans insurance } \\
\hline Contributions & 4.5 & 4.5 & 3.8 & 4.4 & 4.2 & 4.4 & 4.4 & 4.4 \\
\hline Benefits & 4.2 & 4.0 & 4.0 & 3.9 & 3.8 & 4.0 & 4.0 & 3.8 \\
\hline Administrative and interest costs & 0.1 & 0.1 & 0.1 & 0.1 & -0.1 & 0.1 & 0.0 & 0.1 \\
\hline Administrative costs & 0.1 & 0.1 & 0.1 & 0.1 & 0.1 & $\ldots$ & 0.1 & 0.1 \\
\hline Interest costs & 0.1 & 0.1 & 0.0 & 0.0 & -0.1 & & 0.0 & 0.0 \\
\hline Balance & 0.1 & 0.3 & -0.3 & 0.4 & 0.5 & 0.3 & 0.3 & 0.5 \\
\hline \multicolumn{9}{|l|}{ Sickness and accident insurance } \\
\hline Contributions & 2.1 & 2.0 & 2.2 & 2.0 & 1.5 & 0.6 & 0.9 & 1.1 \\
\hline Benefits & 1.9 & 2.0 & 2.1 & 1.8 & 1.8 & 0.5 & 0.4 & 0.5 \\
\hline Administrative and interest costs & 0.4 & 0.4 & 0.4 & 0.3 & 0.3 & 0.2 & 0.3 & 0.3 \\
\hline Administrative costs & 0.3 & 0.3 & 0.3 & 0.2 & 0.2 & $\ldots$ & 0.2 & 0.2 \\
\hline Interest costs & 0.1 & 0.1 & 0.1 & 0.1 & 0.1 & $\ldots$ & 0.1 & 0.1 \\
\hline Balance & -0.3 & -0.4 & -0.2 & -0.2 & -0.6 & 0.0 & 0.1 & 0.3 \\
\hline Severance insurance & & & & & & & & \\
\hline Contributions & 0.05 & 0.05 & 0.01 & 0.04 & 0.02 & 0.05 & 0.02 & 0.02 \\
\hline Interest revenues & 0.02 & 0.02 & 0.02 & 0.02 & 0.02 & 0.03 & 0.03 & 0.02 \\
\hline Benefits & 0.02 & 0.01 & 0.01 & 0.03 & 0.04 & 0.02 & 0.02 & 0.01 \\
\hline Administrative costs & 0.00 & 0.00 & 0.00 & 0.00 & 0.01 & 0.01 & 0.01 & 0.01 \\
\hline Balance & 0.05 & 0.05 & 0.01 & 0.03 & -0.01 & 0.04 & 0.02 & 0.03 \\
\hline Memorandum items: & & & (Numb & $r$ of benefi & iaries or it & sured) & & \\
\hline Number of beneficiaries per category & & & & & & & & \\
\hline Old age and widowers and orphans insurance & 9,057 & 9,496 & 10,154 & 10,520 & 10,855 & 11,387 & 11,465 & 11,949 \\
\hline Old age & 8,000 & 8,351 & 8,922 & 9,237 & 9,506 & 9,942 & 10,225 & 10,640 \\
\hline Widowers and orphans & 1,057 & 1,145 & 1,232 & 1,283 & 1,349 & 1,445 & 1,240 & 1,309 \\
\hline Sickness and accident insurance & $\ldots$ & 12,808 & 12,789 & 12,306 & 12,148 & 10,918 & 10,166 & 11,383 \\
\hline Sickness & $\ldots$ & 11,489 & 11,437 & 11,003 & 10,767 & 9,834 & 9,413 & 10,797 \\
\hline Accident & $\ldots$ & 1,319 & 1,352 & 1,303 & 1,381 & 1,084 & 753 & 586 \\
\hline Severance insurance & 113 & 57 & 56 & 415 & 482 & 228 & 174 & 59 \\
\hline Number of insured per category & & & & & & & & \\
\hline Old age and widowers and & & & & & & & & \\
\hline orphans insurance & 134,526 & $\ldots$ & 145,053 & 169,207 & 145,472 & 142,149 & 145,032 & 156,889 \\
\hline Old age & 57,766 & $\ldots$ & 62,556 & 74,006 & 61,112 & 60,114 & 61,938 & 73,475 \\
\hline Widowers and orphans & 76,760 & $\ldots$ & 82,497 & 95,201 & 84,360 & 82,035 & 83,094 & 83,414 \\
\hline Sickness and accident insurance & 58,004 & 62,054 & 61,404 & 63,582 & 64,037 & 63,366 & 62,278 & 63,733 \\
\hline Sickness & 27,742 & 29,652 & 29,306 & 30,169 & 30,265 & 29,827 & 29,233 & 29,310 \\
\hline Accident & 30,262 & 32,402 & 32,098 & 33,413 & 33,772 & 33,539 & 33,045 & 34,423 \\
\hline Severance insurance 1/ & 30,262 & 32,402 & 32,098 & 33,413 & 33,772 & 33,539 & 33,045 & 34,423 \\
\hline
\end{tabular}

Source: SVB.

$1 /$ Concerns the same category of insured as those insured for accidents. 
Table A13. Aruba: Government Debt, 1995-2003

\begin{tabular}{|c|c|c|c|c|c|c|c|c|c|}
\hline & 1995 & 1996 & 1997 & 1998 & 1999 & 2000 & 2001 & 2002 & 2003 \\
\hline & \multicolumn{9}{|c|}{ (In millions of Aruban florins) } \\
\hline Total & $1,007.1$ & $1,043.2$ & $1,079.9$ & 910.8 & 870.9 & 947.2 & $1,103.6$ & $1,240.6$ & $1,500.0$ \\
\hline Domestic debt & 568.5 & 636.3 & 746.7 & 520.3 & 503.6 & 571.5 & 710.5 & 717.5 & 769.5 \\
\hline Tradable & 139.7 & 194.9 & 220.6 & 186.8 & 189.2 & 165.1 & 179.2 & 189.1 & 218.5 \\
\hline Short term & 32.0 & 32.0 & 32.0 & 32.0 & 40.0 & 37.4 & 48.0 & 48.0 & 48.0 \\
\hline Long term & 107.7 & 162.9 & 188.6 & 154.8 & 149.2 & 127.7 & 131.2 & 141.1 & 170.5 \\
\hline Nontradable $1 /$ & 428.8 & 441.4 & 526.1 & 333.5 & 314.4 & 406.4 & 531.3 & 528.4 & 551.0 \\
\hline Short term & 97.0 & 133.4 & 105.4 & 76.6 & 88.7 & 156.0 & 272.2 & 275.8 & 300.9 \\
\hline Long term & 331.8 & 308.0 & 420.6 & 256.8 & 225.7 & 250.4 & 259.2 & 252.6 & 250.2 \\
\hline Foreign debt & 438.6 & 406.9 & 333.2 & 390.5 & 367.3 & 375.7 & 393.1 & 523.1 & 730.5 \\
\hline Netherlands & 373.2 & 345.1 & 275.9 & 278.2 & 231.0 & 204.4 & 181.5 & 199.7 & 219.7 \\
\hline European investment bank & 22.4 & 21.5 & 19.0 & 19.5 & 16.5 & 14.4 & 13.0 & 15.0 & 17.2 \\
\hline \multirow[t]{2}{*}{ Other } & 43.0 & 40.3 & 38.2 & 92.8 & 119.8 & 156.8 & 198.6 & 308.4 & 493.6 \\
\hline & \multicolumn{9}{|c|}{ (In percent of GDP) } \\
\hline Total & 42.6 & 42.2 & 39.4 & 30.6 & 28.2 & 28.5 & 32.5 & 36.3 & 41.7 \\
\hline Domestic debt & 24.1 & 25.8 & 27.2 & 17.5 & 16.3 & 17.2 & 20.9 & 21.0 & 21.4 \\
\hline Tradable & 5.9 & 7.9 & 8.0 & 6.3 & 6.1 & 5.0 & 5.3 & 5.5 & 6.1 \\
\hline Short term & 1.4 & 1.3 & 1.2 & 1.1 & 1.3 & 1.1 & 1.4 & 1.4 & 1.3 \\
\hline Long term & 4.6 & 6.6 & 6.9 & 5.2 & 4.8 & 3.8 & 3.9 & 4.1 & 4.7 \\
\hline Nontradable 1/ & 18.1 & 17.9 & 19.2 & 11.2 & 10.2 & 12.2 & 15.6 & 15.4 & 15.3 \\
\hline Short term & 4.1 & 5.4 & 3.8 & 2.6 & 2.9 & 4.7 & 8.0 & 8.1 & 8.4 \\
\hline Long term & 14.0 & 12.5 & 15.3 & 8.6 & 7.3 & 7.5 & 7.6 & 7.4 & 7.0 \\
\hline Foreign debt & 18.6 & 16.5 & 12.2 & 13.1 & 11.9 & 11.3 & 11.6 & 15.3 & 20.3 \\
\hline Netherlands & 15.8 & 14.0 & 10.1 & 9.3 & 7.5 & 6.1 & 5.3 & 5.8 & 6.1 \\
\hline European investment bank & 0.9 & 0.9 & 0.7 & 0.7 & 0.5 & 0.4 & 0.4 & 0.4 & 0.5 \\
\hline Other & 1.8 & 1.6 & 1.4 & 3.1 & 3.9 & 4.7 & 5.8 & 9.0 & 13.7 \\
\hline
\end{tabular}

Sources: Data provided by the authorities, and IMF staff estimates.

1/ From 1996 onward, excluding the debt to the public pension fund (APFA), which was canceled following the March 2001 consensus on a framework for the actuarial analysis of APFA and reevaluation of government obligations to this fund. Government debt data excluding liabilities to APFA before 1996. 
Table A14. Aruba: Balance of Payments Summary, 1995-2003

(In millions of Aruban florins)

\begin{tabular}{|c|c|c|c|c|c|c|c|c|c|}
\hline & 1995 & 1996 & 1997 & 1998 & 1999 & 2000 & 2001 & 2002 & 2003 \\
\hline Current account & -27.6 & -110.8 & -350.9 & -25.6 & -742.0 & 416.0 & 594.7 & -589.7 & -278.1 \\
\hline Trade balance & -446.7 & -539.8 & -700.1 & -632.5 & $-1,084.3$ & -100.8 & 96.0 & -948.4 & -596.7 \\
\hline Oil sector & 273.8 & 180.3 & -21.3 & 206.0 & -184.4 & 904.1 & $1,030.6$ & 35.5 & 482.6 \\
\hline Free zone & 28.3 & 71.7 & 84.4 & 42.7 & 48.9 & 3.9 & 9.9 & 13.6 & 12.6 \\
\hline Rest of the economy & -748.8 & -791.9 & -763.2 & -881.2 & -945.7 & $-1,008.8$ & -944.5 & -997.5 & $-1,091.9$ \\
\hline Services & 385.4 & 456.7 & 399.8 & 607.7 & 476.2 & 663.9 & 678.3 & 691.8 & 537.2 \\
\hline Travel and tourism & 794.8 & 907.2 & 957.5 & $1,080.8$ & $1,058.7$ & $1,200.3$ & $1,232.5$ & $1,196.1$ & $1,183.0$ \\
\hline Transportation & -219.9 & -290.4 & -332.0 & -176.9 & -239.5 & -353.6 & -380.1 & -332.7 & -413.5 \\
\hline Government services & -34.3 & -25.5 & -39.8 & -18.0 & -14.8 & -10.1 & -18.0 & -24.6 & -39.2 \\
\hline Other services & -155.2 & -134.6 & -185.8 & -278.2 & -328.1 & -172.8 & -156.0 & -147.0 & -193.1 \\
\hline Income & -16.5 & -21.2 & -30.8 & 8.7 & -54.1 & -16.2 & -77.7 & -211.0 & -67.1 \\
\hline Current transfers & 50.2 & -6.5 & -19.8 & -9.5 & -79.8 & -127.6 & -101.9 & -122.1 & -151.5 \\
\hline Financial and capital account & 62.4 & 53.6 & 315.7 & 184.0 & 797.0 & -483.0 & -441.6 & 591.5 & 165.0 \\
\hline Private capital & 34.3 & 44.7 & 293.4 & 128.6 & 782.1 & -524.0 & -469.6 & 458.1 & 181.5 \\
\hline Oil sector & -23.2 & 109.6 & 326.3 & 107.4 & 663.0 & -428.6 & -577.1 & 372.1 & 79.4 \\
\hline Non-oil sector & 57.5 & -64.9 & -32.9 & 21.2 & 119.1 & -95.4 & 107.5 & 86.0 & 102.2 \\
\hline Government capital & 28.1 & 8.9 & 22.3 & 55.4 & 14.9 & 41.0 & 28.0 & 133.4 & -16.5 \\
\hline Inflows & 47.3 & 27.9 & 38.3 & 71.3 & 28.2 & 90.2 & 49.3 & 173.5 & 324 \\
\hline Grants & 27.1 & 27.9 & 38.3 & 15.7 & 1.4 & 16.8 & 0.0 & 37.4 & 30.0 \\
\hline Loans & 20.2 & 0.0 & 0.0 & 55.6 & 26.8 & 73.4 & 49.3 & 136.1 & 294.0 \\
\hline Outflows & 19.2 & 19.0 & 16.0 & 15.9 & 13.3 & 49.2 & 21.3 & 40.1 & 340.5 \\
\hline Banking sector & 48.0 & 0.0 & 4.9 & -67.7 & -14.0 & 19.9 & 18.5 & 32.9 & -3.8 \\
\hline Errors and omissions & -6.3 & 10.1 & 1.2 & 2.2 & -35.8 & 20.2 & -23.4 & 31.0 & 52.5 \\
\hline Change in reserves $1 /$ & -76.5 & 47.1 & 29.1 & -92.9 & -5.2 & 26.8 & -148.2 & -71.8 & 65.0 \\
\hline
\end{tabular}

Source: CBA.

1/ Including gold, excluding revaluation differences. 
Table A15. Aruba: Balance of Payments Summary, 1995-2003

\begin{tabular}{|c|c|c|c|c|c|c|c|c|c|}
\hline & 1995 & 1996 & 1997 & 1998 & 1999 & 2000 & 2001 & 2002 & 2003 \\
\hline Current account & -1.2 & -4.5 & -12.8 & -0.9 & -24.1 & 12.5 & 17.5 & -17.2 & -7.7 \\
\hline Trade balance & -18.9 & -21.9 & -25.5 & -21.2 & -35.2 & -3.0 & 2.8 & -27.7 & -16.6 \\
\hline Oil sector & 11.6 & 7.3 & -0.8 & 6.9 & -6.0 & 27.2 & 30.3 & 1.0 & 13.4 \\
\hline Free zone & 1.2 & 2.9 & 3.1 & 1.4 & 1.6 & 0.1 & 0.3 & 0.4 & 0.4 \\
\hline Other & -31.7 & -32.1 & -27.8 & -29.6 & -30.7 & -30.3 & -27.8 & -29.2 & -30.3 \\
\hline Services & 16.3 & 18.5 & 14.6 & 20.4 & 15.4 & 20.0 & 20.0 & 20.2 & 14.9 \\
\hline Travel and tourism & 33.6 & 36.7 & 34.9 & 36.3 & 34.3 & 36.1 & 36.3 & 35.0 & 32.9 \\
\hline Transportation & -9.3 & -11.8 & -12.1 & -5.9 & -7.8 & -10.6 & -11.2 & -9.7 & -11.5 \\
\hline Government services & -1.5 & -1.0 & -1.5 & -0.6 & -0.5 & -0.3 & -0.5 & -0.7 & -1.1 \\
\hline Other services & -6.6 & -5.4 & -6.8 & -9.3 & -10.6 & -5.2 & -4.6 & -4.3 & -5.4 \\
\hline Income & -0.7 & -0.9 & -1.1 & 0.3 & -1.8 & -0.5 & -2.3 & -6.2 & -1.9 \\
\hline Current transfers & 2.1 & -0.3 & -0.7 & -0.3 & -2.6 & -3.8 & -3.0 & -3.6 & -4.2 \\
\hline Financial and capital account & 2.6 & 2.2 & 11.5 & 6.2 & 25.8 & -14.5 & -13.0 & 17.3 & 4.6 \\
\hline Private capital & 1.5 & 1.8 & 10.7 & 4.3 & 25.4 & -15.7 & -13.8 & 13.4 & 5.0 \\
\hline Oil sector & -1.0 & 4.4 & 11.9 & 3.6 & 21.5 & -12.9 & -17.0 & 10.9 & 2.2 \\
\hline Non-oil sector & 2.4 & -2.6 & -1.2 & 0.7 & 3.9 & -2.9 & 3.2 & 2.5 & 2.8 \\
\hline Government capital & 1.2 & 0.4 & 0.8 & 1.9 & 0.5 & 1.2 & 0.8 & 3.9 & -0.5 \\
\hline Inflows & 2.0 & 1.1 & 1.4 & 2.4 & 0.9 & 2.7 & 1.5 & 5.1 & 9.0 \\
\hline Grants & 1.1 & 1.1 & 1.4 & 0.5 & 0.0 & 0.5 & 0.0 & 1.1 & 0.8 \\
\hline Loans & 0.9 & 0.0 & 0.0 & 1.9 & 0.9 & 2.2 & 1.5 & 4.0 & 8.2 \\
\hline Outflows & 0.8 & 0.8 & 0.6 & 0.5 & 0.4 & 1.5 & 0.6 & 1.2 & 9.5 \\
\hline Banking sector & 2.0 & 0.0 & 0.2 & -2.3 & -0.5 & 0.6 & 0.5 & 1.0 & -0.1 \\
\hline Errors and omissions & -0.3 & 0.4 & 0.0 & 0.1 & -1.2 & 0.6 & -0.7 & 0.9 & 1.5 \\
\hline Change in reserves & -3.2 & 1.9 & 1.1 & -3.1 & -0.2 & 0.8 & -4.4 & -2.1 & 1.8 \\
\hline
\end{tabular}

Sources: CBA; and IMF staff estimates. 
Table A16. Aruba: Monetary Survey, 1995-2003

(In millions of Aruban florins, end of period)

\begin{tabular}{lrrrrrrrrr}
\hline & 1995 & 1996 & 1997 & 1998 & 1999 & 2000 & 2001 & 2002 & 2003 \\
\hline Net foreign assets & 478 & 431 & 397 & 558 & 577 & 530 & 660 & 699 & 638 \\
Central bank 1/ & 396 & 349 & 320 & 413 & 418 & 391 & 540 & 611 & 546 \\
Commercial banks & 82 & 82 & 77 & 145 & 159 & 139 & 121 & 88 & 91 \\
Net domestic assets & 783 & 870 & 963 & 981 & 1,122 & 1,208 & 1,181 & 1,335 & 1,577 \\
Domestic credit & & & & & & & & & \\
Public sector & 957 & 1,083 & 1,176 & 1,244 & 1,394 & 1,512 & 1,544 & 1,703 & 1,922 \\
$\quad$ Central government & -61 & -42 & -10 & -9 & 12 & -1 & -26 & -62 & -43 \\
$\quad$ Development aid & -52 & -39 & 0 & 1 & 22 & 22 & 6 & 9 & 37 \\
Private sector & -9 & -3 & -10 & -10 & -9 & -23 & -31 & -71 & -79 \\
$\quad$ Enterprises & 1,018 & 1,124 & 1,186 & 1,253 & 1,382 & 1,513 & 1,570 & 1,765 & 1,964 \\
Consumer credit & 609 & 620 & 636 & 636 & 670 & 730 & 740 & 836 & 926 \\
Housing mortgages & 215 & 233 & 269 & 288 & 336 & 357 & 367 & 409 & 435 \\
Other & 186 & 243 & 263 & 301 & 350 & 401 & 445 & 491 & 550 \\
Other items (net) & 8 & 28 & 17 & 28 & 26 & 25 & 18 & 28 & 54 \\
Money supply (M2) & -174 & -213 & -212 & -263 & -273 & -304 & -363 & -368 & -345 \\
Money (M1) & 1,261 & 1,301 & 1,361 & 1,539 & 1,699 & 1,738 & 1,841 & 2,034 & 2,214 \\
Quasi-money & 435 & 445 & 473 & 547 & 590 & 596 & 701 & 845 & 933 \\
\hline
\end{tabular}

Source: CBA, Quarterly and Monthly Bulletins .

1/ Including gold, excluding revaluation differences. 
Table A17. Aruba: Monetary Developments, 1995-2003

\begin{tabular}{lrrrrrrrrr}
\multicolumn{7}{c}{ (Percent change) } \\
\hline & 1995 & 1996 & 1997 & 1998 & 1999 & 2000 & 2001 & 2002 & 2003 \\
\hline Net foreign assets & 6.3 & -9.8 & -7.9 & 40.4 & 3.4 & -8.1 & 24.4 & 5.9 & -8.8 \\
$\quad$ Central bank 1/ & 23.9 & -11.9 & -8.3 & 29.0 & 1.3 & -6.4 & 37.8 & 13.3 & -10.6 \\
Commercial banks & -36.9 & 0.1 & -6.0 & 87.7 & 9.7 & -12.5 & -13.3 & -27.3 & 4.3 \\
Net domestic assets & 4.6 & 11.1 & 10.8 & 1.8 & 14.4 & 7.7 & -2.3 & 13.1 & 18.1 \\
Domestic credit & 4.5 & 13.1 & 8.6 & 5.8 & 12.1 & 8.4 & 2.1 & 10.3 & 12.8 \\
Public sector 2/ & -77.7 & 31.5 & 76.6 & 8.2 & 238.2 & -108.9 & $-2,236.4$ & -141.2 & 31.3 \\
$\quad$ Central government 2/ & -98.9 & 25.0 & 100.3 & 800.0 & $2,311.1$ & -0.9 & -74.0 & 60.7 & 306.7 \\
$\quad$ Development aid 2/ & -8.7 & 70.1 & -276.9 & 0.0 & 4.1 & -140.4 & -38.5 & -126.8 & -11.5 \\
Private sector & 7.2 & 10.5 & 5.5 & 5.7 & 10.3 & 9.5 & 3.7 & 12.4 & 11.3 \\
$\quad$ Enterprises & 5.5 & 1.8 & 2.5 & 0.1 & 5.3 & 9.0 & 1.4 & 13.0 & 10.7 \\
Consumer credit & 1.5 & 8.7 & 15.4 & 6.9 & 16.6 & 6.5 & 2.6 & 11.6 & 6.2 \\
$\quad$ Housing mortgages & 21.7 & 30.8 & 8.3 & 14.3 & 16.5 & 14.3 & 11.1 & 10.4 & 12.0 \\
$\quad$ Other & -1.2 & 237.8 & -37.5 & 61.8 & -6.8 & -2.7 & -28.3 & 55.5 & 90.8 \\
Other items (net) & 4.4 & 22.3 & -0.1 & 23.9 & 3.6 & 11.6 & 19.4 & 1.3 & -6.3 \\
Money supply (M2) & 5.2 & 3.2 & 4.6 & 13.1 & 10.4 & 2.3 & 5.9 & 10.5 & 8.9 \\
Money (M1) & -1.4 & 2.2 & 6.3 & 15.6 & 7.9 & 1.0 & 17.6 & 20.5 & 10.5 \\
Quasi-money & 9.1 & 3.7 & 3.7 & 11.7 & 11.8 & 3.0 & -0.2 & 4.3 & 7.7 \\
\hline
\end{tabular}

Source: CBA, Quarterly and Monthly Bulletins .

$1 /$ Including gold, excluding revaluation differences.

2/ Stock series is typically low and contains negative values; percent change calculations based on the convention that a less negative number or a change to a positive number constitute an increase in domestic credit to the public sector. 
Table A18. Aruba: Changes in Sources of Broad Money, 1995-2003

(Change in percent of broad money at the beginning of the period)

\begin{tabular}{lrrrrrrrrr}
\hline & 1995 & 1996 & 1997 & 1998 & 1999 & 2000 & 2001 & 2002 & 2003 \\
\hline Net foreign assets & 2.4 & -3.7 & -2.6 & 11.8 & 1.2 & -2.7 & 7.5 & 2.1 & -3.0 \\
Central bank 1/ & 6.4 & -3.7 & -2.2 & 6.8 & 0.3 & -1.6 & 8.5 & 3.9 & -3.2 \\
Commercial banks & -4.0 & 0.0 & -0.4 & 5.0 & 0.9 & -1.2 & -1.1 & -1.8 & 0.2 \\
Net domestic assets & 2.9 & 6.9 & 7.2 & 1.3 & 9.1 & 5.1 & -1.6 & 8.4 & 11.9 \\
Net domestic credit & 3.5 & 10.0 & 7.2 & 5.0 & 9.8 & 6.9 & 1.8 & 8.6 & 10.8 \\
Public sector & -2.2 & 1.5 & 2.4 & 0.1 & 1.4 & -0.8 & -1.4 & -2.0 & 1.0 \\
$\quad$ Central government & -2.2 & 1.0 & 3.0 & 0.1 & 1.4 & 0.0 & -0.9 & 0.2 & 1.4 \\
$\quad$ Development aid & -0.1 & 0.5 & -0.6 & 0.0 & 0.0 & -0.8 & -0.5 & -2.2 & -0.4 \\
Private sector & 5.7 & 8.4 & 4.7 & 5.0 & 8.4 & 7.7 & 3.2 & 10.6 & 9.8 \\
$\quad$ Enterprises & 2.7 & 0.9 & 1.2 & 0.0 & 2.2 & 3.5 & 0.6 & 5.2 & 4.4 \\
Consumer credit & 0.3 & 1.5 & 2.8 & 1.4 & 3.1 & 1.3 & 0.5 & 2.3 & 1.2 \\
$\quad$ Housing mortgages & 2.8 & 4.5 & 1.5 & 2.8 & 3.2 & 2.9 & 2.5 & 2.5 & 2.9 \\
Other & 0.0 & 1.5 & -0.8 & 0.8 & -0.1 & 0.0 & -0.4 & 0.5 & 1.3 \\
Other items (net) & -0.6 & -3.1 & 0.0 & -3.7 & -0.6 & -1.9 & -3.4 & -0.3 & 1.1 \\
Broad money & 5.2 & 3.2 & 4.6 & 13.1 & 10.4 & 2.3 & 5.9 & 10.5 & 8.9 \\
Money (M1) & -0.5 & 0.8 & 2.2 & 5.4 & 2.8 & 0.3 & 6.0 & 7.8 & 4.4 \\
Quasi-money & 5.7 & 2.4 & 2.4 & 7.6 & 7.6 & 2.0 & -0.1 & 2.7 & 4.5 \\
\hline
\end{tabular}

Source: CBA, Quarterly and Monthly Bulletins .

1 / Including gold, excluding revaluation differences. 